\title{
Cry me a Jāhiliyya: Muslim Reconstructions of Pre-Islamic Arabian Culture-A Case Study
}

\author{
Peter Webb
}

For all the complexities and evidential complications historians confront when reconstructing the spread of Islam in the Middle East, there is a substructure upon which the whole edifice of early Islam stands, which is yet even more knotty and in need of pressing attention. This historical conundrum is the concept known in Arabic as al-Jähiliyya. Most commentators interpret alJāhiliyya as the pre-Islamic Arabian world into which Muhammad directed his prophetic messages, and al-Jāhiliyya thereby embodies both Islam's formative milieu and the lore of Islam's pre-history, making it a logical starting point for any study that seeks to understand how Islam emerged in Arabia. Yet alJāhiliyya is a conundrum because the world of pre-Islamic Arabia is very difficult to conceptualise. The most detailed accounts were recorded by Muslims after an effluxion of several centuries following Muhammad, and while the Arabic literature offers us a vast store of information, its interpretation presents a double-edged difficulty.

First, we do not know quite how accurately the Muslim-era stories about alJāhiliyya map onto the real cultures and societies of pre-Islamic Arabia, particularly those of al-Hijāz, the region where Muhammad was born. ${ }^{1}$ And second, we do not yet understand the discourses behind the Muslim recording of preIslamic lore, and hence we do not know what kinds of grains of salt we need to take when interpreting the texts. Since both pre-Islam's empirical history and the Muslim literary narratives about it are obscure, positivists, narratologists and historians of other persuasions grapple with Arabic literature about al-

1 The efforts to reconstruct the history of the seemingly "empty Hijāz" are summarised in James Montgomery, "The Empty Hijāz," in Arabic Theology, Arabic Philosophy: From the Many to the One: Essays in Celebration of Richard M. Frank, ed. James Montgomery (Leuven: Peeters, 2006), 37-97. Recent archaeological surveys have revealed little substantive material dating between the mid-fourth century and the time of Muhammad (Zbigniew T. Fiema, Ahmad Al-Jallad, Michael C.A. Macdonald and Laïla Nehmé, "Provincia Arabia: Nabataea, the Emergence of Arabic as a Written Language, and Graeco-Arabica," in Arabs and Empires before Islam, ed. Greg Fisher (Oxford: Oxford University Press, 2015), 395). 
Jāhiliyya with little concrete direction, but because Islam's pre-historic milieu is so self-evidently important, scholars are compelled to resolve the puzzle, and they currently experiment with different methods.

One approach cuts the Gordian Knot by discarding Arabic literature about al-Jāhiliyy a under the premise that it is an "outsider source" of secondary value. ${ }^{2}$ This method accordingly privileges archaeology, epigraphy and Late Antique Greek and Syriac writing to narrate pre-Islamic Arab history. Taking an opposite slant, another group resuscitates the Arabic stories by downplaying the effects of narrative, arguing that Muslim writers of third/ninth and fourth/tenth century literature resembled "antiquarians" with "scrupulous" intentions to accurately record pre-Islamic oral traditions. ${ }^{3}$ My sense is that both approaches have shortcomings: the first undervalues the earliest extant Arabic-language voices when reconstructing Arab history, the second somewhat arbitrarily separates Arabic literature into "myth" and "history," and privileges the texts it considers "history" to reconstruct pre-Islamic Arabia via selections of anecdotes. ${ }^{4}$ Echoing these reservations, some call for a more holistic approach to the Muslim reconstruction of Islam in order to identify the agendas under which Muslims turned pre-Islamic memories into Jahhiliyya stories, and this paper aims to join that enterprise. ${ }^{5}$

2 Greg Fisher, "Editor's Introduction," in Arabs and Empires before Islam, ed. Greg Fisher (Oxford: Oxford University Press, 2015), 2.

3 For explications of this approach, see Aziz al-Azmeh, The Arabs in Islam (Berlin: Gerlach, 2014), 43, 62, and The Emergence of Islam in Late Antiquity (Cambridge: Cambridge University Press, 2014), 173. The methodology is common in Arabists' studies of pre-Islam-see Lawrence Conrad, "The Arabs," in The Cambridge Ancient History, vol. 14: Late Antiquity: Empire and Successors, AD 425-6oo, eds. Averil Cameron, Bryan Ward-Perkins and Michael Whitby (Cambridge: Cambridge University Press, 2001), 678-700 and Irfan Shahid's compendious Byzantium and the Arabs (Washington DC: Dumbarton Oaks, 1984-2009).

4 For critique of Shahid and al-Azmeh, respectively, see Greg Fisher, "Kingdoms or Dynasties: Arabs, History and Identity before Islam," Journal of Late Antiquity 4 (2011):248-249, and Peter Webb, "Review of Aziz al-Azmeh The Emergence of Islam in Late Antiquity," 'Ușūr al-Wusțā 23 (2015): 149-153. For critique of the approach favouring Late Antique sources, see Peter Webb, "Review of Greg Fisher Arabs and Empires in before Islam," Bulletin of the School of Oriental and African Studies 79, no. 3 (2016), 640-642.

5 Gerald Hawting, The Idea of Idolatry and the Emergence of Islam (Cambridge: Cambridge University Press, 1999) and Leor Halevi, "Wailing for the Dead: The Role of Women in Early Islamic Funerals," Past \& Present 183 (2004): 3-39 suggest the antithetical relationship of Jāhiliyya/Islam was constructed by Muslims to define Islam itself; Rina Drory, "The Abbasid Construction of the Jāhiliyya: Cultural Authority in the Making," Studia Islamica 83 (1996): 33-49 proposes an alternative approach, focused on court culture, to explain the drivers behind Muslim Jāhiliyya construction. Susan Stetkevych, "The 'Abbasid Poet Interprets History: Three Qașīdahs by Abū Tammām," Journal of Arabic Literature 1o (1979): 49-64 adds more nuance in claiming that Muslims created two kinds of Jāhiliyya, one a heroic tableau 
But before we plunge into the challenge of reinterpreting the Jahhiliyya stories, it bears remembering that the Arabic literary corpus about pre-Islamic Arabia is too vast and was compiled by too many varied groups of people to enable one comprehensive method of analysis. The building blocks of preIslamic history - poetry, genealogy, stories, maxims, prosimetric heroic histories (ayyām al-'arab) and tales of prophets before Muhammad (asāțīr alawwalin ) - were written, analysed and recast by historians, litterateurs, courtiers, state secretaries, genealogists, philologists, jurists, theologians and others in a continuous 1,200 year-long multipartite process of creative re-interpretation since the earliest extant Arabic writings of the late second/eighth century to the present. The plurality of voices demands sophisticated analysis, and a fresh approach can begin with some critical introspection. Over the past century, there has been substantial discussion of al-Jāhiliyya and pre-Islamic Arabia, such that we now encounter quite widely-embraced and rather negative stereotypes about pre-Islamic "pagan Arab" society. ${ }^{6}$ Consequently, there is present need to reappraise what we think we know by tracing the genealogy of scholarship about al-Jāhiliyya to identify where the current "canonical" opinions originated, and thereby peel back the layers of sources through centuries of European and Arabic writing to test how now emblematic traits of al-Jāhiliyya became iconic. Given the infancy of critical "Jāhiliyya Studies," research can begin on a case-by-case basis, and to that aim, this paper pursues the single issue of lamenting the dead in order to explore the utility of re-building our impressions of al-Jāhiliyya from the ground up.

Juynboll's Jāhiliyya Problem: Lamentation in the Hadith

My inspiration for examining lamentation ritual stems from a desire to highlight a key contribution of G.H.A.Juynboll published in 1983, but which hitherto

preserved in poetry, and the other a more reprobate anti-Islam discussed in historical writing. The spectre of multiple discourses acting to shape varied senses of pre-Islam in Muslim imaginations is suggested in Alan Jones, "The Oral and the Written: Some Thoughts about the Quranic Text," in Proceedings of the Colloquium on Logos, Ethnos, Mythos in the Middle East and North Africa Part One: Linguistics and Literature, eds. Kinga Dévényi and Tamás Iványi (Budapest: Eötvös Loránd University \& Csoma de Körös Society Section of Islamic Studies, 1996), 57-66; and Peter Webb, Imagining the Arabs (Edinburgh: Edinburgh University Press, 2016), 258.

6 The negative stereotyping of al-Jāhiliyya is noted in Peter Webb, "Al-Jāhiliyya: Uncertain Times of Uncertain Meanings," Der Islam 91, no. 1 (2014): 70; a view supported in Nadia El Cheikh, Women, Islam and Abbasid Identity (Cambridge MA: Harvard, 2015), 23. 
has garnered little discussion outside the field of hadith studies. Juynboll produced a stimulating critical survey of the traditions associated with niy ăh $a^{7}-\mathrm{a}$ funerary ritual in which a group of women (sometimes professional mourners) ${ }^{8}$ congregate around a grave and commence loud and public wailing, bemoaning the loss and recounting the virtues of the deceased. Juynboll's research was a challenge to the widely-held belief that niy äha was "one of the customs from the Jāhiliyya generally felt to be incompatible with Islam.."9 Niya $h$ a $a$ wailing does appear to exemplify the universe of ideas conventionally associated with al-Jāhiliyya: Juynboll's predecessors had postulated that al-Jāhiliyya was an era of pre-Islamic Arabian "barbarism"10 which was replaced by Islam's "program of moral reformation in Arabia" (i.e. "civilisation"), ${ }^{11}$ and the spectre of ancient Arabian women clustered around a grave, bearing their hair, wailing and tearing at their breasts seemed a perfect counterpoint to the "civilised," rational Islam where death's inevitability was accepted without excessive emotional display. Scholars before Juynboll indeed did conceptualise niyāḥa as a quintessential pagan Arab custom which Muhammad intended to eradicate, ${ }^{12}$ and their view had apparent corroboration in numerous prohibitions of niy ăha recorded in prophetic hadith where wailing is expressly associated with reprobate pre-Islam:

$7 \quad$ Niya ha practice, though pre-modern Arabic texts often use the term naw frequently encountered in pre-modern Arabic with similar connotation: jawwaba (to tear clothes in mourning), 'awwala (to shriek in mourning), nadaba (to recount the virtues of the deceased).

8 There is some, limited, reference to men performing ritual wailing (see Toufic Fahd, "Niyāha," in Encyclopaedia of Islam, 2nd ed. (Leiden: Brill, 1995), 8:64-65). Though premodern Arabic dictionary definitions stress that it was a women's practice, see Ibn Manzūur, Lisān al-'Arab (Beirut: Dār Șādir, 199o), 2:627.

9 Gautier H.A. Juynboll, Muslim Tradition: Studies in Chronology, Provenance and Authorship of Early Hadith (Cambridge: Cambridge University Press, 1983), 96.

10 Ignaz Goldziher, Muslim Studies, ed. S.M. Stern, trans. C.R. Barber and S.M. Stern (London: George Allen \& Unwin, 1967-1971), 1:202; repeated by Francis E. Peters, The Hajj (Princeton: Princeton University Press, 1994), 21, 36, and Toshihiko Izutsu, Ethico-Religious Concepts in the Qur'ān (Montreal: McGill, 2002), 228.

11 Izutsu, Ethico-Religious Concepts, 29. Goldziher's Muslim Studies drew the specific contrast between barbarism and civilisation.

12 The impression of Muhammad's reviling of nìyāḥa is articulated in Jawād 'Alī, al-Mufașșal fì tārīkh al-'arab qabla al-Islām (Beirut: Dār al-'Ilm li-l-Malāyīn, 1968-1973), 5:152-155; Fahd, "Niyāha," 8:64-65. 
A) "May the wailer [näiha] and he who listens be damned."13

B) "The Prophet prohibited wailing [nawh]."14

C) "Wailing [niyāha] at funerals is a practice of al-Jāhiliyya."15

D) "There are three practices that survive from al-Jāhiliyya: casting aspersions about genealogy, wailing, and predicting rain via the clouds (an$\left.w \bar{a}^{\prime}\right) "{ }^{16}$

E) "We dissociate from those who scratch their cheeks, tear their clothes and mourn with cries of al-Jāhiliyya [da'wā al-jāhiliyya ]."17

Against the weight of all received opinion, and with his typically astute isnād analysis, Juynboll revealed that despite the many express prohibitions of wailing in the recorded hadith, Muhammad never actually forbade wailing himself. Juynboll demonstrated that Muslim abhorrence of the practice was far from uniform, and that the absolute prohibition of niyahha in fact developed in Iraq during the second half of the second/eighth century. ${ }^{18}$ Refuting the long-held view that wailing was widespread in pre-Islamic Arabia and that Muhammad specifically strove to eradicate it, Juynboll proposed that (i) Muslims only adopted the niya ạa ritual after contact with indigenous Iraqis following the Conquests, and (ii) second/eighth century Muslim jurists fabricated the above hadith to justify their new prohibition by forging retrospective impressions that the Prophet himself had forbidden niyāha. ${ }^{19}$

Juynboll's contribution was seminal inasmuch as it deconstructed a longtrusted exemplar of pre-Islamic Arabian ritual, but it also left subsequent researchers with a major problem. Since the hadith's adamant claims that niya ăha was a signature pre-Islamic ritual seem to be a fraud, can any report in the hadith about pre-Islamic Arabia and/or Muhammad's original society be trusted? Juynboll's findings were part of his monograph on the transmission of

13 Abū Dāwūd, Sunan Abī Dāwūd (Riyadh: Dār al-Salām, 1999), al-Janā̉iz: 25.

14 Aḥmad ibn Shu'ayb al-Nasā'̄i, Sunan al-Nasā̄ò (Riyadh: Dār al-Salām, 1999), al-Zīna: 25; Ibn Mājah, Sunan Ibn Mājah (Riyadh: Dār al-Salām, 1999), al-Janā̉iz: 51.

15 Ibn Mājah, Sunan, al-Janā’iz: 51.

16 al-Bukhārī, Șaḥị̣ al-Bukhārī (Riyadh: Dār al-Salām, 1999), Manāqib al-Anșār: 27. There are several variatons of this hadith with differing numbers of Jahhiliyya legacies ennumerated: e.g. al-Tirmidhī, Jāmic (Riyadh: Dār al-Salām, 1999), al-Jānā'iz: 23 counts four: niyāḥa, vying over genealogy, predicting rain by ancient meteorological methods (anwa $\left.\bar{a}^{\prime}\right)$, and infection ('adwā), a practice of identifying the source of mange in infected camels; Muslim, Șahịh Muslim (Riyadh: Dār al-Salām, 1999), al-İmān: 121 only counts two, stated as "remnants of disbelief" (kufr): vying over genealogy and niyāha.

17 al-Nasā'̀̀, Sunan, al-Janā'iz: 17.

18 Juynboll, Muslim Tradition, 106-110.

19 Juynboll, 106-107. 
hadith, and hence the fall-out for Jāhiliyya Studies was outside his purview—he left the historiographical wreckage in his wake and moved on. In what follows here, we endeavour to reassemble the pieces.

\section{Jāhiliyya: The 'Other' of Early Muslim Identity?}

Niyăha was the subject of renewed scrutiny in a 2004 paper by Leor Halevi who, apparently independently of Juynboll's 1983 work, ${ }^{20}$ reached a similar conclusion that the prohibition of niyahha was an invention of early second/eighth century jurists in the prominent Iraqi Muslim town al-Kūfa. Unlike Juynboll, Halevi argues that niy $\bar{a} h a$ likely was a real pre-Islamic Arabian practice, but he concurs that Muhammad (and the early generations of Medinan jurists) never forbade it, and in order to explain the history of niya ăha's proscription, Halevi articulates a several-stepped scheme. He posits that the first stage occurred in late first/seventh-century Iraq when pietistic Kufan jurists, keen to reduce the public activities of women, sought to forbid them from participating in funeral processions and wailing at graves. Halevi argues that women nonetheless persisted in their funerary rites, and so the Kufan jurists took a second step of associating niyāha with the reprobate pre-Islamic al-Jāhiliyya in order to assert the absolute necessity of abandoning the practice. But the ritual continued nonetheless, so the third step of juridical development occurred when jurists resigned to the reality of continued wailing and so fabricated a new hadith (Hadith (D) cited above) that counted niya ha $a$ a set of set of three ${ }^{21}$ preIslamic customs which they expressed as stubbornly enduring despite the rise of Islam. This final step was thereby a face-saving manoeuvre of the jurists that transformed niyāha's persistence in Iraq's Muslim towns from a potentially embarrassing reminder of jurists' failure to control social behaviour, into a prescient sign of Muhammad's foreknowledge of the future "dire failure of the civilizing mission of Islam." ${ }^{22}$

Halevi's niyāha analysis takes the specific case of wailing to appraise the broad function of al-jāhiliyya in early Muslim thought, wherein he proposes that a dialectic relationship existed between pietistic Islam and quotidian practice. He identifies al-Jāhiliyya as "the uncivilized era preceding the rise of

$20 \quad$ Halevi, "Wailing," 5, note 6.

21 As noted above, the number of Jāhiliyya practices ranges between two and four, depending on the narration.

22 Halevi, "Wailing," 29. 
Islam", ${ }^{23}$ and attributes the persistence of niy $\bar{a} h a$ to the operation of "two divergent modes of religiosity" — a "Jāhilī mode" of spontaneous emotional rituals, and an "Islamic mode" characterised by conformity to dogmatic beliefs. ${ }^{24}$ Thereby, he observes that

[i]n practice as in theory the two modes coexisted and were in fact interdependent. Jāhilī rituals were not altogether displaced by the new Islamic rituals, but continued to operate side by side. Islamic rituals simply represented the orthodox standard, an idea to which Muslims renewed their commitment after observing or participating in Jāhilī rites. In this sense, Jāhilī rituals have played an integral role in Islamic history, having worked to re-energize Muslims in their commitment to the cause of Islam. ${ }^{25}$

Underwriting Halevi's conclusion is the opinion that al-Jähiliyya was a "construct of Muslim ideologies interested in defining, by opposition, the ideal Islamic ritual." ${ }^{26} \mathrm{His}$ proposal that al-Jähiliyya acts as Islam's foil, creatively crafted by Muslims to help give tangible form to the meaning of Muslim identity, is attractive and was earlier suggested in Hawting's study of Muslim narratives about idolatry. ${ }^{27}$ Halevi's attention to the function of pre-Islam in Muslim discourses and his efforts to identify the drivers behind Muslim rulings on niyăha thus probe deeper than Juynboll's model, ${ }^{28}$ but the Jāhiliyya-as-other paradigm - howsoever elegantly Foucaultian and with much post-modernist logic to it—does not actually seem to have operated so saliently in early Muslim identity construction.

If Halevi's binary "modes of religiosity" 29 dialectic by which Muslims affirmed their identity through contemplating jăhili practice is to hold true, then it should follow that Muslims (a) derived a cathartic effect from engagement with pre-Islamic memories and ritual, ${ }^{30}$ and $(b)$ that they were conscious of the "oppositional" nature between pre-Islamic and Muslim behavioural patterns.

23 Halevi, 29.

24 Halevi, 31-32.

25 Halevi, 32.

26 Halevi, 16.

27 Hawting, The Idea of Idolatry, 2-5, 151.

28 Juynboll's methods focus on dating the emergence of traditions, and his proposal of a gradual rise in anti-niya h̆ha statements by the early second/eighth century appears cogent, however, his more brief consideration of the reasons (which he ascribes to Muslim women learning the practice in Iraq (Muslim Tradition, 107)), calls for more scrutiny.

29 Halevi, "Wailing," 3 o.

3o Halevi expressly mentions "catharsis," in "Wailing," 32. 
As far as I can tell, however, such a hypothesis does not stand to the scrutiny of wider discourses about pre-Islam in Arabic literature. Muslim reading of pre-Islamic poetry, for example, apparently raised issues of piety in some circles, but the defenders of poetry (and all of its pre-modern Muslim-era readers whose opinions I have so far found), make no indication that the indulgence in reading pre-Islamic verse invoked catharsis or guilt: ${ }^{31}$ prophetic hadith were widely circulated as reminders to Muslims that "poetry contains wisdom"; 32 another hadith is even more positive:

The Prophet—God's blessings upon him - would pray Fajr and then sit in his place of prayer until sunrise and his Companions would converse about stories of al-Jähiliyya and they would recite poetry and they would laugh, and he [the Prophet] would smile. ${ }^{33}$

Attempts to forbid poetry cited Qurān 26:224-227 which castigates poets, but these verses were, in the main, interpreted so as to permit most poetry composition, and did not curb interest in pre-Islamic verse. ${ }^{34}$ For our purposes, we can discern that some circles opposed poetry recitation, while poetry's proponents were the stronger force, and it is key to note that across the arguments about poetry preservation, I have not found its justification on the grounds of pre-Islamic poetry's cathartic effect or edifying value in revealing the folly of

31 The assumption that hadith specialists generally disapproved of poetry (see Michael Cooperson, Classical Arabic Biography (Cambridge: Cambridge University Press, 200o), 910) seems hasty. Hadith collections contain unambiguous defences of poetry (examples are noted below), and hence while some early hadith collectors and/or jurists may have critiqued poetry, they were not a cohesive group, and evidently the majority did condone poetry recitation, even in mosques (see al-Nasāì , Sunan, al-Masājid: 23). The proposal that Muslims approached pre-Islamic poetry analogously to pious Medieval Western European monks who made penance after reading profane classical Latin (Robert Hoyland, Arabia and the Arabs (London: Routledge, 2001, 9)), does not accurately map onto the Muslim context.

32 The hadith is widely reported: see al-Bukhārī, Șaḥịh, al-Adab: 9o; al-Tirmidhī, Jāmic, alAdab: 69 .

33 al-Nasā̄ì, Sunan, al-Sahw: 9o; see a similar hadith in al-Tirmidhī, Jāmic, al-Adab: 7o.

34 The context and exegesis of Qur'ān 26:224-227 is well dissected and argued between Michael Zwettler, “The Sura of the Poets: Final Conclusions?" Journal of Arabic Literature 38 (2007): 111-161 and Irfan Shahid, "The 'Sūra' of the Poets Revisited," Journal of Arabic Literature 39 (2008): 398-423. Zwettler (139-146) duly notes the oppositional relationship between Muhammad's claims of prophecy and poetry in the context of the Qur'ān's revelation, however, the verses do not categorically forbid the production of poetry, especially for later generations. 
pre-Islam. Pre-Islamic poetry was instead considered as something good in and of itself, a repository of proper Arabic language along with a record of Arab knowledge and virtues. In this vein, consider the comment on the jāhili nature of pre-Islamic poetry in Ibn Qutayba's Fadl al-Arab (The Excellence of the Arabs):

Poetry is the summa of Arab knowledge. It is their archive, so study it. And you must learn the poetry of the Hijaz, since it is the poetry of al-Jähiliyya, and it has been exonerated. ${ }^{35}$

The quotation's mention of "exonerated" implies a priori rejection of pre-Islam, but it is ambiguous, since the passage's intent is to urge the study of poetry as the cornerstone of Arab knowledge, and Ibn Qutayba's text relies on preIslamic lore to build his case of Arab excellence. The rehabilitation of poetry continues in Ibn Qutayba's next anecdote: an exchange reported between the early hadith specialists Muslim ibn Bashshār (fl. late first/seventh century) and Sa'îd ibn al-Musayyab (d. ca. 94/712-713).

Muslim ibn Bashshār said: After hearing Saīi ibn al-Musayyab chanting poetry, I asked him, "You recite poetry?" to which he said, "Don't they recite it among you too?" "No," I replied. He then said, "Then you follow a non-Arabic piety [nask ajami ]," adding that the Prophet of God (God bless him) said: "Non-Arabic piety is the worst form of piety." ${ }^{36}$

Ibn Qutayba's discourse seems intended to rebut claims that pre-Islamic poetry is un-Islamic: the healthy exhortations to recite poetry, placed in the mouths of prominent hadith scholars, down-play negative associations of Jähiliyya and promote the conception of poetry as a particular virtue of the Arabs which manifestly trumped trepidation.

The poet Muhammad ibn Munādhir (d. 198/813) explicitly invoked a nonoppositional sense between the Jāhiliyya and Islamic cultural spheres in a poem:

Relate to us some Islamic knowledge ( figh) transmitted from our Prophet

To nourish our hearts;

35 Ibn Qutayba, Fạ̣l al-Arab wa-l-tanbīh 'alā 'ulümihā, ed. Walīd Khāliṣ (Abu Dhabi: alMajma' al-Thaqāfì, 1998), 182-183.

36 Ibn Qutayba, Faḍl, 183. 
Or relate the stories of our Jāhiliyya

For they are wise and glorious. ${ }^{37}$

Ibn Munādhir's Jāhiliyya is not 'othered' by Islam, but instead both are parts of a sense of Arab identity that has both pre-Islamic and Islamic components and merits. I pursue this function of al-Jāhiliyya elsewhere, demonstrating how third/ninth century Iraqi adab discourses about al-jāhiliyya articulated by literary scholars such as Ibn al-Kalbī (d. 204/819 or 206/821), Ibn Ḥabīb (d. 245/859) and al-Jāhịiz (d. 255/868-869) place substantial emphasis on the continuity of laudable pre-Islamic traditions into the Umayyad and early Abbasid Caliphates. ${ }^{38}$ This literary Jāhiliyya was constructed as a device by which Muslims could articulate impressions about Arab character and identity, and was not a diatribe against paganism. ${ }^{39}$ Given that a very sizeable aspect of Jāhiliyya cultural production around Anno 250 focused on praiseworthy Arabness, it is difficult to sustain Halevi's interpretation that references to Jāhiliyya practices served as an axiomatic trigger of revulsion of pre-Islamic Arabian practice.

\section{3}

Al-Jāhiliyya's Footprint in Early Hadith

The 'pro-Jāhiliyya' Iraqi adab litterateurs cited in the previous section could of course have been participating in a separate discourse to that of their contemporary pietistic jurists who narrated the anti-niya hạa hadith, but analysis of the representation of pre-Islam in the largest extant collection of early hadiththe Kufan Ibn Abī Shayba's (d. 235/849) al-Mușannaf indicates otherwise. ${ }^{40}$

Shihāb al-Dīn al-Nuwayrī, Nihāyat al-arab fí funūn al-adab, ed. Hasan Nūr al-Dīn (Beirut: Dār al-Kutub al-'Ilmiyya, 2004), 3:268. Ibn 'Abd Rabbihi, al-Iqd al-farīd, ed. Ibrāhīm alAbyārī (Beirut: Dār al-Kitāb al-'Arabī, n.d.), 2:314 narrates the same poem with 'wonders

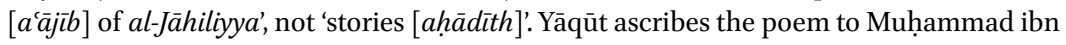
'Abd al-Malik al-Zayyāt, with 'stories [ậāīith]' (Mujam al-Udabā’ (Beirut: Dār al-Kutub al-'Ilmiyya, 1991), 1:61).

38 See Webb, Imagining the Arabs, 258-269 for further analysis of this third/ninth century discourse.

39 This view of an adabJāhiliyya was proposed in Stetkevych, "An Abbasid Poet," and developed in Webb, Imagining the Arabs, 258-269, 315-319.

40 Ibn Abī Shayba's al-Mușannaf and the slightly earlier hadith collection of 'Abd al-Razzāq al-Ṣanānī which it incorporates, have been demonstrated as containing much genuinely early material, representing some of the first surviving layers of Muslim jurisprudence. See Scott Lucas, "Where are the Legal Hadith? A Study of the Muṣannaf of Ibn Abī Shayba," Islamic Law and Society 15 (2008): 283-314 and Harold Motzki, "The Muṣannaf of 'Abd al- 
In al-Mușannaf's compendious collections of hadith on the rules of ethics of Muslim identity and society, it is intriguing that al-Jāhiliyya is not a salient feature of the material's lexicon. Detailed explication of al-Jähiliyya in hadith is beyond the scope of this paper, ${ }^{41}$ but brief comment is in order to contextualise the hadith about niy $\bar{a} h a$ examined by Juynboll and Halevi.

The most salient observation from al-Mușannaf is the stark absence of reference to al-jāhiliyya. According to my readings the word appears only 47 times in the collection's 38,26 o hadith-a frequency of $0.12 \% .{ }^{42}$ If jurists were intending to articulate Muslim faith as a moral reform of pre-Islamic Arabian ways, we could expect them to have made pervasive reference to al-Jähiliyya, but the negligible presence of express Jāhiliyya citation means that the așhāb al-hadith neither articulated Islamic law as a system deliberately reforming pre-Muhammadic Arabia, nor constructed a historical narrative plotting the emergence of Islam as a replacement of one older order. Whereas al-Mușannaf does refer to some of the 'negative' al-Jāhiliyya stereotypes familiar today, ${ }^{43}$ those messages are conveyed in less than 20 hadith dispersed throughout the collection, making it illegitimate to conclude that Ibn Abī Shayba sought to present one coherent image of pre-Islam as Islam's binary opposite. Ibn Abī Shayba in fact narrated a number of hadith condoning practices from al-Jāhiliyya, such as the practice of oaths (al-qasāma) in a blood feud case, ${ }^{44}$ the pre-Islamic fast during 'Āshūrä', ${ }^{45}$ the upholding of marriages, divorces and vows made in al-Jähiliyya ${ }^{46}$ and (pertinently) the permissibility of reciting Arabian lore and poetry. ${ }^{47}$ In these latter hadith, the jurist Ibn Abī Shayba echoes a narrative of Jähiliyya-Islam continuity similar to that presented in the contemporaneous Arabic adab literature noted

Razzāq Al-Sanānī as a Source of Authentic Ahādīth of the First Century A.H.," Journal of Near Eastern Studies 5o (1991): 1-21.

The meanings of al-jāhiliyya in the hadith are part of my Nwo Veni research project "Epic Pasts: Pre-Islam Through Muslim Eyes" (2018-2021). the numbering in Ibn Abī Shayba, al-Muṣannaf, ed. Muhammad 'Awwāma (Jeddah: Dār al-Qibla, 2006) are: 9448, 11456, 11457, 11464, 11465, 12229, 12233, 15416, 17195, 19196, 17197, 17200, 17464, 17724, 17995, 19436, 26415, 26581, 26585, 32298, 32422, 32718, 33008, 33054, $33158,33296,33343,33595,33826,36203,36223,36241,36499,36542,37122,37165,37268$, $38095,38283,38305,38306,38313,38355,38398,38565,386 \circ 5,38889$.

For example, Ibn Abī Shayba, al-Muṣannaf, 11456, 11457 (niyāha), 15416 (idolatry), 32298 (fornication).

44 The hadith is repeated twice, al-Mușannaf, 28383, 37591.

45 Ibn Abī Shayba, al-Mușannaf, 9448.

46 Ibn Abī Shayba, 19436, 37293. See also al-Mușannaf, 37268, 37439.

47 Ibn Abī Shayba, 26581. 
above. The very existence of the hadith imply debate over the permissibility of Jāhiliyya continuities into Muslim communities, but since the hadith often affirm them, al-Mușannaf's ambivalent treatment of al-Jāhiliyya coupled with the overwhelming scarcity of express reference to al-Jāhiliyya engenders the impression that pre-Islam was not a principal juridical category or legislative device in the early period.

When reconsidering the ways in which al-Mușannaf attempts to articulate Muslim identity, there is a patent sense of othering, but it does not concern preIslamic Arabia, rather it invokes the Iraqi Muslims' contemporary Zoroastrians (majūs), Christians, Jews, Byzantines (rūm), non-Muslims (al-dhimma) and non-Arabic speakers (acajim). In the Kitāb al-Adab (Book of Ethics) section of al-Mușannaf, for example, the hadith which Ibn Abī Shayba compiled emphasise how members of the Muslim community should interact and communicate with each other in a reciprocal brotherly fashion, suggestive that adab in Ibn Abī Shayba's conception was an ethical boundary that regulated, delineated and identified the Muslim community. In this vein, Kitäb al-Adab contains manifold exhortations to greet non-Muslims differently, to act differently towards them, and to eschew their customs: Muslims are told to stop listening to Iraqi qușșāss storytellers, ${ }^{48}$ to stop playing chess and to avoid undue reading from books. ${ }^{49}$ On the flipside, Muslims are positively urged to continue practicing archery, ${ }^{50}$ to carry weapons into the mosque, ${ }^{51}$ to speak correct Arabic and to relish stories of the Arab al-Jāhiliyya. ${ }^{52}$ Building on the important attention Kister directed to the importance early Muslims attached to "not assimilating",53 we can apprehend that jurists were far more concerned about the risks of assimilation in the present than they were about eradicating pre-Islamic legacies from the past.

Pursuing the discourse further, readers will find that Ibn Abī Shayba's Kitāb al-Adab conveys a consistent message of eschewing Iraqi and preserving Arabian practice. From a narratological angle with the assistance of Bakhtin's "chronotope", we could propose that Ibn Abī Shayba represents laudable timespace as embodied in past Arabia in contrast to the fragile, potentially fraught time-space of his Iraqi present. The narrative is concerned with the cultural

\footnotetext{
48 See Ibn Abī Shayba, 26714-2672o.

49 Ibn Abī Shayba, 2683o.

50 Ibn Abī Shayba, 26154.

$5^{1} \quad$ Ibn Abī Shayba, 26082.

52 Ibn Abī Shayba, 26581.

53 Meir J. Kister, "'Do Not Assimilate Yourselves ...': Lä Tashabbahū," Jerusalem Studies in Arabic and Islam 12 (1989): 321-371.
} 
significance of the time elapsed between pre-Conquest 'Arabian ways' and the cosmopolitan Abbasid-era Iraq, and Ibn Abī Shayba invites his contemporaries to culturally travel back in time to shun effects of their assimilating present. As such, the time-space of pre-Islamic Arabia is valued quite differently from modern impressions about of al-Jāhiliyya. Narratives projecting pre-Islamic Arabians as reprobate 'barbarians' are necessarily side-lined by Ibn Abī Shayba since he presents the Arabians of Muhammad's day as external from contact with the practices and ideas of Iraqis of the second/eighth century in order to proffer them to his audience as a model of the 'authentic' culture of the first Muslims. Ironically, therefore, the pre-Islamic past actually had a positive function for early Muslim jurists. The ancient Arabian ways were not practices which Muslims should shun, on the contrary, some pre-Islamic customs helped to delineate the 'inside' identity of Muslim community, distinguishing them from their non-Muslim Iraqi contemporaries. Herein, the scope for constructing al-Jāhiliyya as an antithetical pre-Islam is almost nil-reflecting the statistically insignificant citation of the word in al-Musannaf.

Ibn Abī Shayba was a hadith collector, and his al-Mușannaf consequently holds a pastiche of juridical opinions and discourses developed in Islam's first two centuries, which means that generalising statements about his intentions are difficult to sustain. But while his hadith present several guises of al-Jāhiliyya in different contexts, it is at least clear that a sweeping impression of 'bad' preIslamic Arabia qua anti-Islam cannot be applied to all (or, indeed, most) of Ibn Abī Shayba's material. To link these findings with our analysis of niyāha, Ibn Abī Shayba does relate one relevant hadith: "those who strike their cheeks, rip their clothes and wail like people of al-Jähiliyya [ahl al-Jähiliyya] are apart from us", ${ }^{4}$ but since Ibn Abī Shayba so infrequently refers to al-Jāhiliyya elsewhere in al-Mușannaf, the associations drawn between wailing and pre-Islam cannot legitimately be situated within a pervasive pietistic discourse of binary religious modes as Halevi hypothesised. Al-Mușannaf's so meagre references to reprobate pre-Islam engender the impression that the now familiar Jāhiliyya/Islam divide only matured somewhat later, and tracking it back into the second/eighth century risks anachronistic reading of Ibn Abì Shayba. The semantics of al-Jāhiliyya were not inert, and texts indicate that a gradual consolidation of its meaning as a negative by-word for "pre-Islamic Arabs" sharpened in the centuries after Ibn Abī Shayba. ${ }^{55}$

54 Ibn Abī Shayba, al-Mușannaf, 11456, 11457.

55 See Webb, "al-Jāhiliyya," 76-79. 
Since al-Mușannaf is manifestly concerned with differentiating Muslims from Christians, Jews and Zoroastrians, Juynboll's opinion that niya ha learned from non-Muslim Iraqis could, prima facie, be at the root of the hadith's prohibition. Halevi's article explores wailing practices in Zoroastrianism, Judaism and Christianity, and finds striking examples of a kind of Jewish niyāha practiced in Iraq, ${ }^{56}$ which seem good candidates to support Juynboll's proposal, but I do not think the case can rest here. If the nawäin wailing women were a borrowing from Judaism, the hadith would certainly have castigated the practice by express identification with Jewish-ness, since elsewhere the hadith so readily cite Jews (and other non-Muslim communities) in the context of othering prohibitions. Conversely, for niya ha a the hadith specifically refer to al-Jāhiliyya, and thus they deposit wailing in a different, and much more niche category of repudiated ritual. Given the overall absence of reference to Jāhiliyya elsewhere in al-Muṣannaf, the placement of niyăḥa in such a special category calls for more specialist analysis, inviting us to pursue our study beyond hadith, interrogating material outside the purview of both Juynboll and Halevi's studies.

\section{Mourning Reconsidered: al-Mubarrad's Kitāb al-Ta $\bar{a} z \bar{\imath}$}

Perhaps because the hadith so unambiguously prohibit niyāha and deride it as a relic of al-Jāhiliyya, modern studies on pre-Islamic mourning practices tend to privilege hadith as the primary source for exploring the interplay between memories of pre-Islamic rituals and Muslim reconstructions of al-Jähiliyya, ${ }^{57}$ but there is a wealth of lesser-studied Arabic literature, poetry and philology which houses potential to sustain a rethink of the function of niya ha $a$ in Muslim imaginations. In the wake of Juynboll's thorough deconstruction of the

56 Halevi, "Wailing," $35^{-36 .}$

57 Juynboll's niya hạa study was wholly reliant on hadith. Likewise Halevi's main evidence was drawn from the hadith corpus: his engagement with poetry is primarily mediated through the study of Thomas Emil Homerin, "Echoes of a Thirsty Owl: Death and Afterlife in Pre-Islamic Arabic Poetry," Journal of Near Eastern Studies 44 (1985): 165-184 (Halevi, "Wailing," 4), though none of the poetic examples in Homerin's article actually contain reference to n-w-h wailing. Jawād 'Alì's survey of pre-Islamic funerary rites is also primarily constructed from hadith ('Alī, al-Mufașsal, 5:152-155). El Tayib similarly begins his short survey of lamentation poetry with the axiom "women must weep" without venturing more specific analysis (Abdulla El Tayib, "Pre-Islamic Poetry," in Arabic Literature to the End of the Umayyad Period, eds. A.F.L. Beeston et al. Cambridge: Cambridge University Press, 1983). 
hadith's empirical authority on the subject, it becomes essential to integrate such alternative sources into our analysis about how and why second/eighth century hadith seemingly invented the prohibition of niyäha.

To reappraise Muslim opinions on funerary rites, analysing a third/ninthcentury monograph expressly composed on the topic of lamentation has evident advantages over gathering scattered references to mourning in the hadith, and the Basran litterateur al-Mubarrad's (d. 287/898) Kitāb al-Ta'āzì wa-l-marāthi (Book of Condolences and Elegies) appears an ideal starting point. It proffers a detailed account of lamentation via extensive citation of poetry (preIslamic and Muslim-era) alongside al-Mubarrad's own editorial comments which help elucidate his intentions. Al-Mubarrad's home, al-Bașra, was not the original seat of the second/eighth century anti-niyahha hadith which emerged in the more northerly Iraqi centre of al-Kūfa, but by al-Mubarrad's day in Anno 250, the collections of various hadith scholars such as Ahmad ibn Hanbal and the widely-travelled compilers of the 'Six Books' demonstrate the thorough dissemination of hadith prohibiting niya ha $a$ across the central Islamic lands. ${ }^{58}$ Given the context, $a l-T a ' \bar{a} z \bar{\imath}$ plots an intriguing middle ground between weeping and stoicism when confronting death.

Al-Mubarrad's thesis is express at the outset of al-Ta'iazi. It explains that while we all know that mankind's existence is fleeting and that permanence is reserved for God, death is nonetheless a shock, and hence good condolences are needed to help the bereaved navigate grief attendant upon the passing of close friends. ${ }^{59} \mathrm{~A}$ good condolence, in al-Mubarrad's view, is one that moves the bereaved to cease lamentation, as revealed in al-Mubarrad's opening anecdote describing how 'Alì swallowed his sorrow on the death of the prophet Muhammad by recalling that Muhammad had prohibited distress $\left(j a z^{c}\right)$ and exhorted fortitude (șabr). Al-Mubarrad builds the argument for șabr via his second anecdote that relates 'Abd Allāh ibn Arāka al-Thaqafi's poem addressed to his excessively weeping bereaved brother. The poem acknowledges that tears will flow, but admonishes with a call for fortitude:

$5^{8}$ The early third/ninth century Ibn Abī Shayba was Kufan, and his anti-niyāha a hadith may represent a local flavour at the time as Juynboll noted (Muslim Tradition, 132), but the frequent repetition of anti-niya ăha hadith in the later third/ninth century Ibn Hanbal's Musnad and the 'Six Books' compiled by widely-travelled hadith specialists originally from Eastern Iran (see notes 13-17) attest to the prohibition's spread during the course of the third/ninth century.

59 Abu al-'Abbās Muḥammad ibn Yazīd al-Mubarrad, Kitāb al-Ta'āzī wa-l-marāthī, ed. Khalīl Manșūr (Beirut: Dār al-Kutub al-'Ilmiyya, 1996), 5 . 
Think on it: if you judge tears can revive the dead

Then cry all your worth for the departed 'Amr.60

Al-Ta'a $z \bar{\imath}$ continues with extensive quotations from poetry and prose admonition connected, in the main, to the deaths of important leaders of the early Muslim community. In describing responses to the deaths of 'Ali's many descendants (the Ahl al-Bayt), al-Mubarrad explores how tears flowing amongst the early Shi'a were stemmed by wiser admonition. Great and worthy men had been unjustly killed in the past to the detriment of the whole Muslim community, and because no tears could retrieve them nor save the trajectory of Islam's history, what justification remains for us to cry over the comparatively insignificant deaths in our families and quotidian circles? But while al-Mubarrad demonstrates how early Muslims overcame tragic loss through fortitude, he does not actually castigate sobbing. For example, al-Mubarrad admires the rational elegy of Mutammim ibn Nuwayra, even though the poet's tears swelled when he once recited the poem in the presence of the Caliph Abū Bakr, ${ }^{61}$ and al-Mubarrad approves of the Umayyad-era nobleman Arțāt ibn Suhayya al-Murrī who took residence in mourning upon the grave of his son for exactly one year, after which he promptly desisted, quoting the poet Labìd:

For a year I'll weep, but then I bid you farewell.

One who cries for a year can be excused. ${ }^{62}$

In an overt theological context, al-Mubarrad also suggests a reason for some lengthy tears in the case of the mourning Mālik ibn Dīnār who lamented his departed brother: "My eyes will not dry until I know whether you're are in Heaven or Hell; but I won't know that until we meet again!"63

The uncertainty of salvation thus adds tension to the sadness of bereavement, and al-Mubarrad explains that "Lamentation poetry [al-marāthī] and its stimuli will remain with humanity to the end of time, since the world will never stop inflicting adversity until it itself ceases to exist."64 In sum, al-Mubarrad establishes that crying for the dead is not wrong in itself, but the bereaved have a duty to realise that worse has befallen better people in the past, and that fortitude is therefore the better path. The eventual triumph of fortitude over initial

\footnotetext{
6o al-Mubarrad, al-Ta'āzī, 6 .

61 al-Mubarrad, 16.

62 al-Mubarrad, 35 .

63 al-Mubarrad, 36 .

64 al-Mubarrad, 159.
} 
tears is the Muslim way-epitomised in al-Mubarrad's lengthy treatment of the pious Caliph 'Umar ibn 'Abd al-'Azīz (r. 99-101/717-720) who found solace following the death of his son in the plague by consoling himself with the knowledge that his son had died a good Muslim and was thus in a suitable state to receive God's great mercy. ${ }^{65}$

Al-Mubarrad's stance in $a l-T a ' \bar{a} z \bar{\imath}$ thus aligns with both Juynboll's observations about the Muslim juridical acceptance of crying $\left(b u k \bar{a}^{\prime}\right)$ which the jurists considered "definitely different from bewailing (niyāha)", and Halevi's proposed Islamic mode of religiosity whereby grief is eased by the rational recognition of the impermanence of the world and the mercy of the afterlife. ${ }^{66} \mathrm{But}$ in terms of pre-Islamic practice, $a l-T a \bar{a} z \bar{l} \bar{l}$ exhibits greater complexities than Juynboll and Halevi's Jāhiliyya/Islam dichotomy would anticipate. Far from disparaging pre-Islamic wailing as a jāhilī religious mode, or even associating wailing with pre-Islam, al-Mubarrad expressly praises the pre-Islamic Arabs' approach to bereavement:

Even though the Arabs of al-Jāhiliyya had neither faith in the afterlife nor fear of eternal damnation, they would urge fortitude [șabr] as they knew its merit. They would chastise those who lamented the deceased, and instead urged resolution [hazm], equanimity [hilm] and virtue [murüa $]$ ... this is corroborated in their poetry and stories reported about them. ${ }^{67}$

Contrary, therefore, to modern received opinion about al-Jāhiliyya, al-Mubarrad in fact condones pre-Islamic mourning practice, and throughout al-Tacia $z \bar{l}$, he likens pre-Islamic elegy and lamentation practice to Islamic-era examples. ${ }^{68}$ Likewise, al-Mubarrad identifies the literary qualities of a successful elegy that mixes feelings of despair with praise for the deceased in poetry of both eras. ${ }^{69}$ Al-Mubarrad describes pre-Islamic elegiac poetry as "famous, admired and esteemed,"70 and he lauds equanimous pre-Islamic Arabs and their practice of enumerating the virtues of the deceased as a way to console loss. Al-Mubarrad also relates an anecdote in which the Caliph Abū Bakr approves of an elegy by the pre-Islamic Zuhayr ibn Abī Sulmā, remarking that the ways in which Zuhayr praised the pre-Islamic leader Harim ibn Sinān would be appropriate words

\footnotetext{
65 al-Mubarrad, 4 o.

66 Juynboll, Muslim Tradition, 107; Halevi, "Wailing," 13.

67 al-Mubarrad, $a l-T a \bar{a} z \bar{\imath}, 7$.

68 See al-Mubarrad's glosses to it, al-Ta'āzīi, 12.

69 al-Mubarrad, 19.

70 al-Mubarrad, 12.
} 
by which to remember the prophet Muhammad. ${ }^{71} \mathrm{Al}$-Mubarrad also adds a further story in which the Caliph 'Umar ibn al-Khatțāb acclaims an elegy by Mutammim ibn Nuwayra which the poet sung "until tears swelled in his eyes."72

Across the anecdotes that render al-Mubarrad's $a l-T a ' \bar{a} z \bar{\imath}$ a veritable history of Arab lamentation, there is no emphasis on equating niya ha $a$ with reprobate pre-Islamic mourning. Reference to wailing via the root $\mathrm{n}$-w-h is very limited, and numerically it is split evenly in al-Ta'āz $z$ 's selections from Muslim-era and pre-Islamic verse. ${ }^{73} \mathrm{~A}$ prose letter ascribed to the 'pious Caliph' 'Umar ibn 'Abd al-'Azīz seeks to discourage people from both crying $(b u k \bar{a})$ and wailing (nawh), citing the authority of the Prophet, but, in keeping with the tenor of all anecdotes in al-Mubarrad's Ta'äzí, the Caliph's wise admonition is neither cast as a diatribe against pre-Islamic ways nor alludes to excessive wailing practices. ${ }^{74}$ Likewise, a reader finds no reference to corrupt pre-Islamic ethics either: $a l-T a ' \bar{a} z \bar{l}$ 's anecdotes craft the impression that people mourned the dead similarly before and after Muhammad, that the wise have always admonished them, and that pre-Islamic Arabs were as successful in eschewing irrational lamentation as Muslims. ${ }^{75}$

Al-Ta'a $z \bar{z}$ accordingly mirrors other third/ninth century literature (and many of Ibn Abī Shayba's hadith too) in its construction of pre-Islamic Arabia as the precursor to the meritorious ways of Muslim-era Arabs. Whilst pre-Islamic Arabians are cast as lacking the monotheistic belief of Muhammad's community, $a l-T a ' \bar{a} z \bar{\imath}$ presents their characters as nonetheless good and embodying key virtues central to proper Muslim ethics. ${ }^{76} \mathrm{Al}-\mathrm{Ta} \bar{a} \bar{a} z \bar{\imath}$ thereby contributes to a discourse which, as I have proposed elsewhere, constitutes one of the principal themes of Iraqi literature at Anno 250: the lauding of "original Arabness"-

71 al-Mubarrad, $18-19$.

72 al-Mubarrad, 16. Al-Mubarrad's impression of the poem as a paragon of elegy is interestingly at odds with the modern-era El Tayib's view that the poem "has the spirit and values of the pre-Islamic era" ("Pre-Islamic Poetry," 89). The poem's ability to shift between moral paradigms says much about the shifting nature of those paradigms themselves.

73 Al-Mubarrad reports two pre-Islamic examples of express niyanha in the poems of alNābigha al-Dhubyānī and in the context of leader's death in the pre-Islamic war of Dāhis and al-Ghabrā' (al-Ta'âżì 20, 163), and for the Muslim-era, he reports poems of al-Farazdaq and Muslim ibn Walīd (al-Ta'āzì, 53, 94).

74 al-Mubarrad, al-Ta'āzì, 40.

75 See al-Mubarrad, $a l-T a ' \bar{a} z \bar{l}, 17$ where al-Mubarrad expressly draws the reader's attention to the virtuous elements in a pre-Islamic poem.

76 Al-Mubarrad articulates a similar argument in his al-Kämil where, for example, he reinterprets the supposedly pervasive pre-Islamic Arabian ritual female infanticide ( $w a^{\prime} d$ ), arguing that very few pre-Islamic Arabs ever actually practiced it (see al-Mubarrad, alKāmil, ed. Muḥammad Aḥmad al-Dālī (Beirut: Mu’assasat al-Risāla, 2008), 2:6o4-6o8). 
imagined as an ethno-cultural continuity between pre-Islamic and early Muslim-eras - in order to praise Islam's formative milieu and (in some cases) obliquely critique perceived ills of cosmopolitan Iraqi Muslim urban society. ${ }^{77}$ In this vision of history, pre-Islamic Arabia is lifted out of 'barbarism': its practices are redrawn as precursors to the even greater Arab achievements in early Islam, and traces of potentially negative pre-Islamic Arabian irrationality common to our present-day impressions of al-Jähiliyya are scarcely visible. ${ }^{78}$

From the sources considered so far, therefore, literature from Anno $25^{\circ}$ neither supports the now conventional opinions about the putatively outlandish pre-Islamic Arabian niya h̆ ritual, nor theories about the supposed 'foil' function of al-Jāhiliyya in Muslim thought. Al-Mubarrad's narrative confounds impressions that Muslim-era scholars marshalled niyāha to chide pre-Islamic Arabs or to define Muslim identity via othering pre-Islam, and moreover, alMubarrad's insistence on the rationality of pre-Islamic elegy calls into question whether professional wailing was ever a central component in pre-Islamic Arabian funerary ritual. In order to pursue the question of al-Jähiliyya, its Muslim reconstruction and Arabian society at the dawn of Islam, we now need to peel back another layer from Kitāb al-Ta'âzi and evaluate the pre-Islamic poetry corpus itself.

Niyāha and Arabic Lamentation Poetry

Pre-Islamic elegy (al-rith $\left.\bar{a}^{\prime} / a l-m a r \bar{a} t h \bar{\imath}\right)$ is preserved in Muslim-era poetry collections, and in order to examine the functions of and the memories recorded about niyăha in Arabic elegiac poetry, anthologies entitled al-Hamāsa offer germane data. Hamāsa collections are celebrations of the lusty heroic and martial values of pre-Islamic Arabians, and Muslim-era collectors gathered selections from what they considered the best verses on the subjects of war and bravery, and also added chapters on other core themes of pre-Islamic poetry, in particular nasīb (opening nostalgic verse), hija $\vec{a}^{\prime}$ (lampoons), and elegies. The collections were much copied, commented upon and circulated, the kinds of poetry they contain were known to medieval Muslims as Diwān al-Arab (the archive of the Arabs), and hence the Hamāsa constitute valuable compendiums on

77 Webb, Imagining the Arabs, 244-269, 337-340.

78 The intriguing emphasis on pre-Islamic Arabian monotheism is a central part of what seems to have been a wider discourse engaged in lauding pre-Islamic Arabian nobility so as to construct an sense of ancestry that was appropriately flattering for Muslim-era Arab elites (see Webb, Imagining the Arabs, 261-268). 
what Muslims believed represented the best and first-hand testimony about core "Arab values" from pre-Islam into the early Abbasid era. Here, we shall survey references to niya âha and mourning in the earliest extant Hamāsa collection, compiled by the third/ninth century Abū Tammām (d. 231/845), and in a seventh/thirteenth century text, al-Hamāsa al-Bașriyya compiled by 'Alī ibn Abī al-Faraj al-Bașrī (d. 656/1258). ${ }^{79}$

To a large extent, both collections mirror the impressions imparted in alMubarrad's al-Ta'āzi about the pre-Islamic Arabs' efforts to remain stoic upon news of death. The poems do commonly reference the public announcement of a death (na'y), with frequent allusions to crying $(b u k \bar{a}$ ) and related/derived words $)^{80}$ and tears of the bereaved, ${ }^{81}$ but the poems, in the main, shift quickly from tears to praise of the deceased (usually a warrior) with almost all verses dedicated to enumerating the hero's virtues, while a number also refer to fortitude $(s a b r)$ as an antidote to tears. ${ }^{82}$

The stoic poems highlight the virtues of men; there are examples, on the other hand, where women are associated with crying and even are expected to cry on the news of a hero's death, as the poetess Fātima bint al-Ahjam exhorts herself:

Cry every morning, my eye!

Empty out all your tears for al-Jarrāh. ${ }^{83}$

In another poem, a girl is upbraided for her apparently excessive grief, but she retorts:

They allege I am too anguished,

But is crying 'Woe is me' so much? ${ }^{84}$

79 Abū Tammām's al-Hamāsa survives in different commentaries made upon it, this paper uses that of al-Marzūqī (d. 421/1030), Sharh Dīwān al-Hamāsa eds. Ahmmad Amīn and 'Abd al-Salām Hārūn (Cairo: Maṭba'at Lajnat al-Ta'līf wa-l-Tarjama wa-l-Nashr, 1968); 'Alī ibn Abī al-Faraj al-Bașrī, al-Ḥamāsa al-Bașriyya, ed. 'Adil Sulaymān Jamāl (Cairo: al-Khānjī, 1999).

8o The references to $b u k \bar{a}$ ' crying mirror the hadith's acceptance of moderate sobbing at funerals which, as Juynboll notes Muslim jurists "felt to be something definitely different from bewailing (niyāha)," Muslim Tradition, 107.

81 Abū Tammām's al-Hamāsa makes regular reference to $b u k \bar{a}$, while in al-Bașrī's collection, allusions to crying are ubiquitous.

82 See, for examples, al-Marzūqī, Sharh, 2:797, 888, 90o, 3:1112.

83 al-Marzūqī, 2:9o9.

84 al-Marzūqī, 3:1082. 
Interestingly the poetess defended her tears, explaining that she does not feel she weeps so excessively, thereby calling into question the extent to which wailing was an expected female role, while another verse recounts how both men and women are equally moved to tears:

Oh! How much has Watīra ibn Sammāk

Aroused the tears of men and women. ${ }^{85}$

As a rhetorical device, reference to tears of both sexes is a praise for the deceased. The poets intimate that people (especially men) should be stoic upon hearing the news of death, but in the cases of the eulogised hero, the allusion to uncontrolled and/or effusive flow of tears demonstrates how calamitous the death was to the community, and, by extension, how important a man the deceased must have been. This same device continued in Muslim-era verse: consider the line of al-'Abbās ibn al-Ahnnaf, where the poet's expected fortitude $(s a b r)$ gave way to tears:

After your passing, I called out to fortitude,

But I answered instead to tears. ${ }^{86}$

And the pre-Islamic poet Ka'b ibn Sa'd al-Ghanawī considers one man's legacy great enough as to deserve tears of a ba akiya female mourner of free-birth (implying that he would chide such public mourning in less deserving circumstances):

I will not blame a free-born women

If she mourns you with tears and sighs. ${ }^{87}$

Crying therefore appears skewed towards female responses to death, but it is not a unique preserve of women, and it would accordingly be hasty to presume from the above verses that a strict gender division was in effect whereby stoic men were surrounded by throngs of irrational, shrieking women at pre-Islamic funerals. ${ }^{88}$ Overall, we find the women's poetry both stoic and distinctly proud,

85 al-Marzūqīi, 2:938.

86 al-Bașrī, al-Hamāsa, 2:759.

87 al-Bașīi, 2:687.

88 El Tayib expresses a common impression that "women must weep", and considers women's poetry more emotional than male-composed elegies, though he later notes that some male-composed elegies do contain emotion similar to female (85 and 88). When amal- 
there are specific references to women not crying ${ }^{89}$ and women poets praise the virtues of sabr (patience and fortitude) in styles and imagery akin to men's poetry. For example, Māwiyya bint al-Ahatt's elegy has no tears, and commends her brothers' șabr in the face of death on the battlefield:

They could have been excused in fleeing,

But they saw fortitude the more noble path. ${ }^{90}$

While Māwiyya's own restraint from weeping in favour of recounting the men's glory is her form of șabr.

Furthermore, and in conformity with the over-arching theme of resilience in the elegies, the paucity of reference to niya ha $a$ is striking. From the 237 poems in the Rithä chapter of Abū Tammām's al-Hamāsa, there are only four that contain wailing words related to the root n-w-h, ${ }^{91}$ and references to related wailing practices such as standing over the grave, "howling" (described by the root 'w-l), bare-headed mourners (hawäsir), cheek-scratching and clothes-tearing are equally infrequent, appearing in only six further verses. ${ }^{92}$ Al-Hamāsa alBașriyya is similar: of its 184 poems, only nine contain express reference to niyāha and other exaggerated wailing practices. ${ }^{93}$ And outside of the Hamāsa genre, I likewise found scant reference to niyāha wailing and nawä ịh wailers in surveys of other collections of pre-Islamic poetry. Details and the qualitative aspects of specific examples will be considered presently — from a quantitative perspective, it seems that the specific wailing words (unlike the sobbing vocabulary related to the verb $b a k \bar{a}$ ) were not part of the common elegiac lexicon.

Thus, reference to niya $\bar{a} h a$ in the hadith far outstrips its allusion in preIslamic poetry, which ostensibly bolsters Juynboll's hunch that wailing was adopted by Muslims after they left Arabia, and that jurists retrospectively fab-

gamating rithä poetry, generalising conclusions become difficult to sustain. Various examples in the Hamāsa collections where a pre-Islamic male poet begins a poem with description of his own tears before transitioning to self-admonishment exemplifies the difficulties in positing strict gender rules on pre-Islamic poetry and social norms.

89 The poetess 'Amra al-Kath'amiyya expresses indigance that people "allege" (za'ama) she is distraught, and replies that she merely feels the loss without excessive emotion (alBașrī, al-Hamāsa, 2:665), and likewise the poems of Laylā al-Akhyaliyya and Zaynab bint al-Tathriyya give no indication of tears, and instead praise the deceased in stoic terms (alBașrī, al-Hamāsa, 2:655-659).

90 al-Bașrī, 2:69o.

91 al-Marzūqī, Sharh, 2:799, 859, 973, 3:1065.

92 al-Marzūqī, 2:877, 991, 799, 995, 996, 3:110o.

93 al-Bașrī, al-Hamāsa: n-w-ḥ: 2:616, 651, 728, 777; '-w-l: 2:640, 695, 716, 728; h-s-r: 2:716. 
ricated hadith to depict niyăha as a pre-Islamic practice, but I would hesitate to settle on this conclusion. The word does exist in the old Arabian poetry, so the practice cannot have been simply 'invented' in second/eighth century al-Küfa. Also, the poetesses cited in the Hamāsa collections are freeborn women, hence there may have been a more sizeable class of slave-mourners who wailed but

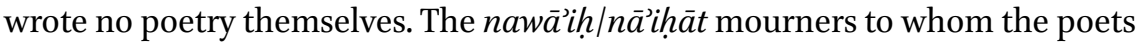
occasionally refer could be such lowbred professional wailers, but even so, the evidence is intriguing since the few references in the Hamäsa collections to the phrase "sending out wailers/nawäi $h$ " occur only in Muslim-era poems. ${ }^{94}$ When pre-Islamic-era poets describe exaggerated wailing, they often make express reference to freeborn women: Dìk al-Jinn's line is unambiguous:

I said: the freewoman must wail $\left[i^{c} w \bar{a} l\right] !^{95}$

And al-Rabī' ibn Ziyād al-'Absī engages more detail:

In the light of dawn

Bare-headed women sing his elegies.

They who used to hide their faces

Now expose to on-looking eyes,

Freeborn women beating their faces,

In memory of the fine, gracious young man. ${ }^{96}$

Although neither of these poems uses the word niy ăha or words from the $\mathrm{n}$-w-h root, both are articulating a ritual of embellished mourning practiced by free-born women. To interpret these pre-Islamic lines, they again can be read as poets' strategies to express that the particular death they commemorate was so calamitous that even freeborn women must wail, bear-headed and in public, relegating them to a public display usually practiced just by an underclass of professional mourners or slaves. Given these indications, exaggerated wailing emerges as a ritual present in pre-Islam, in contradiction to Juynboll, but it is nonetheless curious that pre-Islamic elegiac poetry makes such infrequent reference to such formal lamentations and very infrequent express mention of niyăḥa. If public wailing was widespread before Islam, we should expect the poets to have invoked it more often as a literary device signifying grief. Into the conundrums and equivocal evidence, we are thus invited

94 See al-Bașrī, 2:616; al-Marzūqī Sharh, 2:699, 859.

95 al-Bașrī, al-Hamāsa, 2:695.

96 al-Bașrī, 2:716-717. 
to re-scrutinise niyāha's precise meaning and its place in the universe of preIslamic and Umayyad-era mourning patterns to determine how exactly we can interpret it as a historical phenomenon.

Although niya ạha is infrequent in pre-Islamic poetry, it is certainly present in poems composed around the time of Muhammad's prophecy (as enumerated shortly), and there are reasoned philological theories about the root n-w-h that suggest that the word does have pre-Islamic Arabian origins. Most pre-modern Arabic dictionaries derive niy $\bar{a} h a$ from the verb tanāwaha (to congregate at a place). Although it is somewhat unusual to derive a first-form noun from a tafáala verb, semantically, the derivation has merit: the verb tanāwaha is quite common in pre-Islamic poetry (especially in an onomatopoeic connotation for wind swirling about a place), and since the verb appears much more frequently than the niya ă ation was a borrowing from the earlier established verb. ${ }^{97}$ Whilst Ibn Manzūu's (d. 711/1311) dictionary, Lisān al-'Arab reports the 'wind' definition after his discussion of niya ăha 'wailing,' suggesting that wailing is the root n-w-h's primary meaning, ${ }^{98}$ earlier dictionaries state the that the semantic development went the opposite way: they report that noun for wailer $(n \bar{a} i \grave{h} a)$ originated from the verb to congregate (tanāwaha). ${ }^{99}$ Ahmad ibn Fāris' (d. 375/985) Maqāȳ̌s al-lugha, a dictionary specifically focused on elucidating the root connotation of Arabic words, likewise explains that the n-w-h root means "close meeting" (muqābala), either for adjacent mountains, swirling winds, or gathered wailers. ${ }^{100}$ The corpus of pre-Islamic poetry, where the 'wind' connotation outnumbers the instances where n-w-h connotes wailing, suggests the early Arabic lexicographers were correct in deriving the 'wailer' noun from the 'congregate' verb.

97 Various collections of pre-Islamic poetry contain verses where the verb tanāwaha describes the wind gathering/swirling: see al-Bașrī, al-Hamāsa, 1:214, 'Abd al-Malik ibn Qurayb al-Așmaīì, al-Așma ìyyāt, ed. Muḥammad Nabīl Țarīfī (Beirut: Dār Șādir, 2005), 122, Labīd, Dīwān, ed. Iḥsān 'Abbās (Kuwait: Wizārat al-Irshād wa-l-Anbā’', 1962), 319.

98 Ibn Manzūur, Lisān al-'Arab (Beirut: Dār Șādir, 1990), 2:627.

99 See al-Khalīl ibn Ahmad, al-'Ayn, eds. Mahdī al-Makhzūmī and Ibrāhīm al-Sāmarrāīì (Baghdad:Wizārat al-Thaqāfah wa-l-I'lām, 1980), 3:304; Abū Bakr Muhammad ibn Durayd, Jamharat al-lugha, ed. Ramzī Ba'albakī (Beirut: Dār al-'Ilm li-l-milāyīn, 1987), 1:575.

100 Aḥmad ibn Fāris, Maqāȳ̌s al-lugha, ed. 'Abd al-Salām Muhammad Hārūn (Damascus: Ittiḥād al-Kuttāb al-'Arab, 2002), 5:367. 
The 'gathering' root is sensible because wailers naturally 'gather' around a tomb to perform their commemoration, and the Arabic dictionaries adduce a related noun manāha (lit. a place of congregation) as connoting a grave. The grave-monuments may have originated in sacred spaces, if a verse reported in Ibn Durayd's (d. 321/933) dictionary Jamharat al-lugha which describes horsemen gathered (tanāwaha) in the "best part of a wadi" (sarārat al-wādī) does extend, as Ibn Durayd suggests, to a legitimately ancient practice associating choice land with ritual acts..$^{101}$

When people (men and women) congregated at the (sacred) manăha, we are told that they would extol the virtues of the departed, ${ }^{102}$ and in this sense the verb năha shares meaning with the verb nadaba to connote a eulogising praise ritual, and this tallies with the preserved pre-Islamic poetry, since the verses are focused in recounting the departed's glories in life. As such, any public performance of most of the elegiac rith $\bar{a}^{3}$ poetry could be called niy $\bar{a} h a$, and the word might then trace its origins to gatherings for communal ritual commemorations at particular tombs.

Much rith $\bar{a}^{\prime}$ poetry also contains explicit invocations for the heavens to water the grave with abundant rain, ${ }^{103}$ and herein mourners' tears might have symbolised a man-made water offering, inviting the clouds to follow suit. The divine importance of water is attested across Mesopotamian cultural production and it has natural resonance for desert-domiciled peoples, and hence it is quite plausible that niya ha as a collective poetic ritual involving (a) praise of the deceased's virtues, and (b) the offer of tears-cum-water would have been an appropriate ceremony for pre-Islamic Arabians. Nowhere, however, is excessive wailing and loud lamentation implied in the philological derivation, nor in the ritual that may originally have been connected to it, and the hadith's association of niy ăha with such exaggerated practice is therefore curious.

Into this challenge, a verb nāha is also attested in pre-Islamic poetry and some dictionaries to describe the cooing of doves. ${ }^{104}$ The late sixth century poet al-Nābigha al-Dhubyānī connected cooing with lamentation in a verse describing a crow's reaction to the death of its chick:

\footnotetext{
101 Abū Bakr Muhammad ibn Durayd, Jamharat al-lugha, ed. Ramzī Bacalbakī (Beirut: Dār al-'Ilm li-l-milāyīn, 1987), 1:575.

102 Nashwān al-Ḥimyarī, Shams al-'ulūm, ed. Ḥusayn ibn 'Abd Allāh al-'Umarī (Damascus: Dār al-Fikr, 1999), 10:6799.

103 The rain/tears/watering the grave motif is common, see examples in al-Bașrī, al-Hamāsa, 2:728, al-Marzūqī, Sharh, 2:934, 3:1037, 1055 .

104 al-Khalīl ibn Aḥmad, al-Ayn, 3:304; Ibn Manzūur, Lisān, 2:627. For an example in early poetry, see Abū Sa'īd al-Ḥasan al-Sukkarī, Sharh ash'ār al-Hudhaliyyīn, eds. 'Abd al-Sattār Ahmad Farrāj and Maḥmūd Muḥammad Shākir (Cairo: Maktabat Dār al-'Urūba, n.d.), 1:138.
} 
A crow, high on a soaring peak

Spied its dead chick, and cried $(n \bar{a} h \bar{a} \bar{a}) .105$

If the connotation of cooing birds was derived from human funerary lamentation, then the verb originally would have meant to congregate, and as it became synonymous with congregation at a burial, crying was added to its semantic universe. But even if this tentative chronology is correct, the infrequency of reference to niy ăha coupled with the fact that none of the verbs related to n-wh connote excessive or loud wailing as implied by the technical term niyāha in the hadith, means that it is still unclear why hadith collectors so scorned niyāha and depicted elaborate wailing as a quintessential practice of the pre-Islamic al-jāhiliyya.

To propose a resolution, it is worthwhile to re-examine the chronology and connotation of poems in which niya ha $a$ and related exaggerated wailing practices appear. Chronologically, the verb nāha with a meaning of "loud wailing" is very rare in early pre-Islamic poetry. The compilers of Arabic dictionaries (who usually mustered poetic evidence to help define words) cite the poetry of Labìd and the Hudhalī poet Abū Dhu'ayb in their definitions of niya hạa: ${ }^{106}$ both are mukhadram poets - their lifespans crossed the period of Muhammad's prophecy, and some of their poetry was therefore composed in the environment of expanding Islam in Arabia. Likewise, the poetess al-Khansā' who occasionally (but not in the majority of her poems) describes niyāh $a$ and other wailing terms was also mukhadrama. And, as alluded above, the majority of references to niyāha in my readings occur in Muslim-era poetry. Poets such as the Umayyad al-Farazdaq and Asja' ibn 'Amr al-Sulamī, ${ }^{107}$ and the Umayyad/Abbasid Abū 'Ațā al-Sindī108 included the motif of "sending out wailers" to emphasise the status of figures they praised. Consider also the Abbasid-era poet Muslim ibn al-Walìd (d. 208/823), who says in his elegy of al-Faḍl ibn Sahl:

When I found no relief from burning sadness

And tears were the only cure for grief,

I sent out wailers [anwāh ] for your memory

Shaking wailers [nawāi $h]$ recounting your glories. ${ }^{109}$

105 al-Nābigha al-Dhubyānī, Dīwān, ed. Muḥammad Abū al-Faḍl Ibrāhīm (Cairo: Dār alMa’̄āif, 1990), 213.

106 Muḥammad ibn Aḥmad al-Azharī, Tahdhīb al-lugha, ed. Muḥammad 'Abd al-Raḥmān Mukhaymir (Beirut: Dār al-Kutub al-'Tlmiyya, 2004), 4:122; Ibn Manzūū, Lisān, 2:627.

107 al-Bașrī, al-Hamāsa, 2:616.

108 al-Marzūqī, Sharh, 2:799.

109 al-Mubarrad, al-Ta'āzì, 94. 
On the basis of the frequency of citation, niyanh $a$ wailers appear as more an Islamic-era phenomenon than pre-Islamic, and to add further complexity, a number of pre-Islamic poems which do mention excessive public acts of crying or bare-headed crying women which we might think qualify as niyāha do not actually use the word. ${ }^{110}$ From a chronological perspective, therefore, the term niyāha emerges in a miniscule number of ancient verses, obtains a more visible footprint in poems composed around Muhammad's lifetime (either shortly before or after his prophecy), and then becomes better established in the lexicon of Muslim-era elegy.

In terms of signification, the instances of exaggerated wailing ascribed to the poets in the generations before the prophet Muhammad are connected with mourning the death of very high-status men. During the wars known as Dāhis and al-Ghabrā', the death of the tribal leader Mālik ibn Zuhayr ibn al-Rawwāha occasioned pertinent verses: ${ }^{111}$

For the likes of him women go out bareheaded (hawāsir)

And stand moaning (mu'wila) into the dawn.

Another variant of the poem is narrated:

Bareheaded women recount his virtues (yandabnahu)

Beating their faces into the dawn.

They scratch their cheeks over the fallen brave

An upright man whose merits travelled far. ${ }^{112}$

Tarafa ibn al-'Abd, the pre-Islamic eastern Arabian poet of distinguished lineage likewise does not mention niyāha expressly, but makes a request for similar exaggerated lamentation upon his own death:

Should I die, then announce my death in the way I deserveTear at your clothes, Daughter of Mabad!

Do not treat me like you would an insignificant man

You shall find none to replace me. ${ }^{13}$

\footnotetext{
110 See al-Marzūqī, Sharh, 2:963, 991, 3:110o.

111 al-Mubarrad, al-Ta'àzzì, 163 .

112 al-Marzūqī, Sharh, 3:1065.

113 Țarafa ibn 'Abd, Dīwān, eds. Duriyya al-Khațīb and Luṭ̂ĩ al-Ṣaqqāl (Beirut: al-Mu’assasat al-'Arabiyya li-l-Dirāsa wa-l-Nashr, 20oo), $5^{6}$.
} 
The above poems engender the impression that exaggerated wailing was an act that could accompany the burial of a high-status individual, and in this context, the demand for freeborn women to bear their heads, beat themselves and wail audibly plays to a symbolic affirmation of the deceased's status. The ritual asserts that the male leader, when alive, was capable of defending his group's women, and now, upon his passing, the women express 'respect' via exaggerated display of grief representing their perception of present defencelessness. The women thereby humiliate themselves in mimesis of the humiliation they now risk as falling captive, since they have none to defend them.114 The ritual of self-humiliation of freeborn women attested in pre-Islamic poetry underlines the relative rarity of events that could trigger niyāha: if niyāha was commonplace, it would loose its symbolic effect, and hence logic can imagine that actual displays of exaggerated mourning in reality were restricted to very high-status deaths. In poetry, the men's requests that they receive such wailing thereby act as a form of self-praise: the men seek to secure their memory as elite warriors by asserting themselves as deserving of exaggerated niyăha. Such an explanation would help explain why the word is so infrequent in the surviving poetry, as we could now propose that wailing was known and associated with pre-Islamic communal congregations about the graves of leaders, but the number of aspirational men who wished to be wailed-upon after their death exceeded the number who actually received such an honour. Modern impressions that niyăha was a commonplace practice of al-Jāhiliyya have misread the significance of the poetry's intent: it describes a ritual associated with particular shock and communal grief, not a commonplace personal expression of everyday loss. Pre-Islamic Arabia was accordingly not a theatre of excessive irrational wailing, rather such practice was synonymous with the highest-class form of funerary rite, and poets summon the wailing vocabulary as a rhetorical means to express their own aspirations to be remembered as heroic leaders.

The theory mirrors the story connected to a reference to niya hạa at the dawn of Islam when the leader 'Âmir ibn al-Ṭufayl reportedly asked the poet Labīd: "If something happens to your uncle [i.e. 'Âmir means himself], what will you say?" And Labīd recited a poem, opening it with

Rise and stand with the wailers (anwāh $)$

In a ritual in the early morn.

114 The sense of humiliation is evident in the poetry—see for example the poem of Rabí` ibn Ziyād al-'Absī cited above, note 96. 
The freeborn women scratch their fair cheeks, Wearing black clothes of coarse hair. ${ }^{115}$

The poet's graphic image of exaggerating wailing responds directly to his patron's request with the usual hyperbolic exaggeration of praise poetry. And in another poem, Labīd cites niyăha wailing to describe lightning:

Thunder on high, groaning like she-camels separated from their calves Or moaning like wailers (anwāh $)$ in their torn garments. ${ }^{116}$

Contemporary with Labīd, the poet Abū Dhu'ayb al-Hudhalī also cited niyạha metaphorically in the description of a bull, ${ }^{117}$ and such metaphorical employment of niyăha to conjure meanings of respect and grandeur further suggests that niya $\bar{a} h a$ was indeed a practice reserved for special occasions of weighty significance. But the metaphor could only achieve its rhetorical effect of signifying greatness if the practice was reasonably well known, and herein, the express reference to niya h̆ha in poetry from the early seventh century AD, i.e. the period of Muhammad's Prophecy, offers relevant indications.

Labīd, ${ }^{118}$ Abū Dhu'ayb al-Hudhalī, al-Khansā', Șakhr al-Ghayy, the Christian Abū Zubayd al-Ṭā'i 119 and several lesser-known poets ${ }^{120}$ offer us the first chronological concentration of niyăha allusion in Arabic poetry, suggestive of a poetic-composition environment at the outset of the seventh century where the term was gaining currency to describe a funeral rite. Moreover, as noted above, it was in the generations that followed, when Umayyad and early Abbasid poets made relatively frequent use of the term, and Muțarrif alHujaymī, an elegiac poet of the Numayr settled in the Eastern Iranian city of Merv, even acquired the sobriquet Abū al-Anwāh (the Father of Wailers). It was also in the Muslim-era that a poem referencing niyāha was fabricated and ascribed to the pre-Islamic al-Nābigha al-Dhubyānī, again an indication of a novel broad application of wailing terminology in early Islam. ${ }^{121}$

115 The poem is related in Labīd, Dīwān, 332. For the story, see Muhammad Ibn Ḥabīb, alMuhabbar, ed. Ilse Lichtenstadter (Hyderabad, 1942), 372-373.

116 Labīd, Dìwān, 9o.

117 al-Sukkarī, Sharḥ, 1:101.

118 Labīd also refers expressly to wailers and proper burial ritual in the context of his own tribal group (Dīwān, 282). He is one of the earliest major Arabic poets to so frequently use words formed on the n-w-h root.

119 Abū Zubayd al-Ṭāìì, Dēwān, ed. Nūrī Ḥamūdī al-Qaysī (Baghdad: al-Macārif, 1967), 83.

120 See their poems in al-Bașrī, al-Hamāsa, 2:551, 541, 619 .

121 See al-Nābigha, Dīwān, 228; the verse is counted by the collection's editor as "poems ascribed to al-Nābigha which are not in collections of his verse". 
If the uptick in poetic reference to niyăha just before the dawn of Islam indicates a newfound popularity for the practice in the wider society of Muhammad's milieu, the poetry of the Hudhayl collected in the Muslim-era by the third/ninth-century poetry specialist al-Sukkarī could help our understanding of the ritual's early popular spread. Al-Sukkarī's Hudhali Dìwān collects the poetry of a range of poets, most of whom lived during or shortly before Muhammad's prophecy, and it is - according to my reading - the most concentrated single collection of wailing terminology derived from the n-w-h root. Abū Dhu'ayb references wailing for a high status individual (nawh al-karim); in another poem he promises to dispatch "bear-headed female wailers" (nawh ... hawāsir) whom he also promises to accompany in the funerary commemoration. ${ }^{122}$ Abū Dhu'ayb's younger contemporary, Șakhr al-Ghayy laments his son, Talīd:

My sobbing for Talīd reminds me

Of a dove, cooed to by its kin.

And it responds in kind to them,

Like a wailer $(n \bar{a} i h h a)$ joining the standing lament. ${ }^{123}$

Șakhr al-Ghayy begins another lament for Talìd with express reference to the wailer:

The sound of the wailer by night,

At Sablal, she does not slumber with the sleepers. ${ }^{124}$

Al-Muntakhil's elegy to his son Athila recounts the deceased's virtues and ends with a promise to dispatch loud wailers (nawh ... zajal) for him. ${ }^{125}$ Sāiida ibn Ju'ayya twice uses the verb năha to describe a grieving woman; ${ }^{126}$ the earlier pre-Islamic Hudhalī poet 'Abd Manāf ibn Rib' al-Jurabī describes a funeral, including

The two girls accompany the wailing

Lashing themselves with beats of their sandals. ${ }^{127}$

\footnotetext{
122 al-Sukkarī, Sharh, 1:101, 138, 149.

123 al-Sukkarī, 1:292.

124 al-Sukkarī, 1:293.

125 al-Sukkarī, 3:1284.

126 al-Sukkarī, 3:1162-1163.

127 al-Sukkarī, 2:672.
} 
Al-Jurabī's verse refers to a specific kind of sandal (sibt) apparently made from cow leather and which appears with unusual frequency in poetry of the Hudhayl to describe the implement with which women severely beat themselves during the niya $\bar{a} h a$ ritual (the beating with the sibt sandal is accompanied by the verb lacaja - to inflict burning pain). ${ }^{128}$ Such specialised vocabulary of niya $h a$ and the sibt concentrated in the Hudhayl's poetry points to a rather unique speciality of the group's funerary rituals, prompting new inferences regarding the wider citation of wailing which we find in subsequent Muslimera verse.

The frequency of niyahha reference in the Hudhayl tribal poems composed around the time of Muhammad can help bridge the dearth of reference to niya ha in pre-Islamic poetry compared to the frequency of citation and familiarity with the practice noted in Muslim-era verse. From the poetic evidence, niy $\bar{a} h a$ first musters in the poetry of the Hudhayl who resided in the central alHijāz adjacent to Mecca, and it diffuses across the wider gamut of Arabic poetry in the precise period when the Meccans and other Hijāzīs spread themselves across the Middle East in the Muslim Conquests. The Hudhayl's poems intimate that the practice of niya ạha was becoming popular in Hijāzi regional circles around the dawn of Islam, and so it would follow that Hijāzīs then spread the practice across the wider Middle East when they settled the conquered lands. Instead of thinking niyăha was a pan-Arabian Jähiliyya practice, therefore, we could narrow the ritual to a burgeoning late sixth/early-seventh-century fad of central al-Hijāz that gained a disproportionate footprint in subsequent literature thanks to the spread of Hijāzīs under the flag of the religio-political system of the Caliphate. The evidence therefore invites us to read the dawn of Islam as a key factor in the spread of niy $\bar{a} h a$ - not as part of the religious creed, but as a cultural practice of those people who played a central role in Islam's political spread.

Niyāha wailing thus appears as yet another example of the variegated cultural map of pre-Islam whereby ritual and practice exhibited considerable regional variation. Though third/ninth century writers stressed that niyāha was a pan-Arabian ritual; Juynboll's careful scholarship revealed this to be false, and there is no need for us to perpetuate errors of third/ninth century writing by imagining niyāha was a signature ritual of all pre-Islamic Arabians. While the presence of niya ha in poetry of the early seventh century AD is a decisive corrective to Juynboll's argument that Muslims only adopted the practice after they left Arabia, Juynboll was likely correct when he argued that Muhammad

128 Abū Dhu'ayb also references the sibt, al-Sukkarī, Sharh, 1:191. See also 1:414, 3:1162, 1163. 
never strictly forbade niyāha, and I suggest (following the lead of extant poetry) that peoples in other corners of Arabia were not engaged in its frequent practice.

Herein, analysis of niya hạa is instructive for methods of studying pre-Islamic Arabia in general. There is a tendency to subsume pre-Islamic Arabia's population into one more or less culturally homogenous community which extrapolates any localised practices attested in Arabic lore into phenomena imagined as common to a whole pan-Arabian society. ${ }^{129}$ But the region was never politically unified before Islam and there is little reason to assume that it was culturally and ethnically uniform either. In support of the fragmented preIslamic Arabia model I have argued elsewhere, ${ }^{130}$ it emerges from the foregoing that pre-Islamic funerary practices were likewise not homogenised and that reference to a ritual in one poem does not impute a continuity of practice across the whole 'Arabian Jāhiliyya.' Poetry taken in the round indicates that niy $\bar{a} h a$ 's wide manifestation was relatively late, and we should therefore eschew the generalising tendency inherited from late Muslim writers to unify pre-Islamic verse into archetypal models, since the poetry itself contains sufficient variation to indicate that practices evolved between periods and locales.

\section{Muslim niyāḥa and Its Conversion into a 'Pre-Islamic' Ritual}

To conclude this essay, we should like to investigate why niyăha, given its scant pre-Islamic footprint, became one of the archetypal attributes of 'bad' Arabian Jāhiliyya as conventionally understood today. The straightforward answer would posit that Muslims rejected wailing as incompatible with Islam, and hence projected their abhorrence onto an imagined pre-Islamic Arab past, thereby inventing the spectre of a wailing Jahhiliyya. But the foregoing demonstrates that this is very unlikely: Muslims did not have such a universally and thoroughly negative opinion of pre-Islam, and the practice of niyahha actually appears wider-spread in Islamic times than in pre-Islam. We are therefore invited to weigh other factors, and, considering the usual development of intel-

129 With specific reference to niyăha, Tayib's analysis of elegy is emblematic of the scholarly tendency, as he notes that the references to women beating themselves in rhythmic lament is particularly prominent in the poetry of Hudhyal, but from that he immediately extrapolates that it was a practice of "pre-Islamic Arabia" (El Tayib, "Pre-Islamic Poetry," $85)$.

130 Webb, Imagining the Arabs, $77-85$. 
lectual discourses and historical reconstructions in other contexts, it seems imprudent to presume prima facie that one over-arching agenda prompted all Muslims to develop a 'canonical' opinion about niyăha. Arabic literature is not a uniform corpus created by a single cadre of litterateurs: texts were generated from manifold angles and interests of cultural production, and this section will suggest an array of possibilities which together may have constituted a critical mass of opinion which eventually enabled a wholesale rewriting of preIslamic history into the current, familiar stereotype where wailing stands as a quintessence of irrational Jāhiliyya. Our investigation begins by questioning why the Qurān and Muhammad himself were silent on niyạha, and how the subsequent unfurling of Muslim peoples across the Middle East added new ingredients that reshaped niy $\bar{a} h a$ 's significance and connotations.

Niyāha and its emotive emphasis on bemoaning past glories of the deceased does clash with a general thrust of Muhammad's message to navigate bereavement with fortitude and hope for the better future so expressly promised in the Qur'ān, but if our analysis of the poetry is correct in identifying niya ha a as a ritual particular to nomads in al-Hijāz, we can venture an explanation as to why Muhammad did not take pains to prohibit it himself (and why later jurists therefore had to retrospectively castigate the practice). Muhammad's prophecy was focused in urban settlements, and the Muslims' nomadic allies were, in most respects, outside the ambit of strict adherence to Muhammad's rulings: nomads $\left(a^{\prime} r \bar{a} b\right)$ were largely castigated as outsiders unless they performed a hijra (immigration) to Muslim centres. ${ }^{131}$ Hijra was the central act for perfecting faith in the opinion of early Muslim communities, ${ }^{132}$ and hence the law was directed towards settled communities, entailing that Muhammad's concern for rituals of nomadic groups outside the boundaries of his Medinan hijra community was limited-after all, much of Islamic communal legal regulation was not binding on $a^{\prime} r a \bar{b}$ groups. Niya ăha performing $a^{\prime} r a \bar{b} b$ were thus not the principal subjects of nascent Islamic law, and the relatively niche mourning ritual

131 The key status distinction between Emigrant-Muslim (muhäjir) and Bedouin (a'rāb) is well argued in Khalil Athamina, "A'rāb and Muhājirūn in the Environment of Amșār," Studia Islamica 66 (1987): $5^{-25}$. Fritz Steppat further develops the investigation into the $a^{\prime} r a \bar{b}$ 's lower status in early Islam (“'Those who believe and have not emigrated': The Bedouin as the Marginal Group of Islamic Society," in Islão e Arabismo na Península Ibérica: Actas do XI Congresso da União Europeia de Arabistas e Islamólogos, ed. Adel Sidarus (Évora: Universidade de Évora, 1986), 403-412).

132 The importance of hijra in giving shape to the identity of the first Muslims is set out in Patricia Crone, "The First-Century Concept of Higra," Arabica 41 (1994): 352-387 and Ilkka Lindstedt, "Muhājirūn as a Name for the First/Seventh Century Muslims," Journal of Near Eastern Studies 74 (2015): 67-73. 
of nomadic groups could consequently elude Muhammad's juridical priorities and the authentic memories of his hadith.

Matters changed significantly in the generation after Muhammad by virtue of the Conquests which spread both urban Muslims and their Bedouin allies across the Middle East, and fundamentally transformed senses of status both across the region and inside Conqueror communities. Prior to the Conquests, Arabian communities had their own social stratifications and boundaries demarcating nobility within groups alongside inter-group status rankings, and these were delineated and constrained by the confines of Arabian resources, territory and the boundaries of surrounding empires. When the Conquests dismantled the Byzantine and Sasanian hegemons and spread the small Arabian groups across an unprecedentedly vast and rich territory, Arabiansqua-Muslims constituted a new pan-Middle Eastern elite in their proprietary towns (the amșār) with monopolies over resources that allowed previously subaltern Arabian groups to sense novel high status and power as the main beneficiaries of tax revenues and power-brokers in the early Caliphate. Given that niyăha had been a ritual associated with men of high status amongst the nomadic groups who constituted the backbone of Conquest armies, the numbers of men considering themselves worthy of elite-niya ă $a$ following the Conquests would have been vastly greater than at any time before, and, as the poetry demonstrates, larger numbers of Arabian warriors perpetuated niy $\bar{a} h a$ practice in the new cities of the Caliphate.

Umayyad-era niyăha was accordingly not a means for ex-nomadic Muslims to remember some Jähiliyya practices as a counterpoint-foil to help them understand Islam, rather niyāha spread as a consequence of Islam's rising star: the more important Muslims felt their personal status was, the more they demanded wailing at their funerals. And herein, in the context of an environment with an expanded class of nouveau-elites exaggerating their lamentation rituals, jurists - who were usually not from the same warrior elite class - might be expected to have taken offence. From their perspective, a practice theologically out of kilter with their interpretation of Islamic ethics was spreading amongst the Muslim elite as a result of Islam's success, and niyāha's growing presence in Muslim society thereby attracted a limelight which had not been so evident to Muhammad and the very first layer of Muslim juridical thinking. The anti-niyăha hadith thus represent the efforts of the non-Arabian jurists to curb (and perhaps exert pressure on) the military elites.

The jurists' dim view of niyāha can therefore be explained both via sociopolitical and theological factors. The former constituted a friction between different classes of Muslim society, the second represented different normative conceptions of Islam. Precisely why the jurists castigated niyāha in terms 
of Jāhiliyya, however, remains unaccounted for, since voicing prohibitions in terms of Jāhiliyy a was not the jurists' most usual tactic to express opprobrium. Other factors need be brought into our consideration.

Niyāha's Jāhiliyya connection appears to have intersections with apocalyptic eschatological beliefs which were widespread, but much under-studied, in Islam's first two centuries. ${ }^{133}$ Muslims embraced apocalyptic eschatology from the very beginning of Islam, and the frequent fighting over the Caliphate between Muslim groups (the fitna, pl. fitan) over the 200 years after Muhammad fed apocalyptic discourses, embedding holy fear and violence into the social fabric of early Islam. ${ }^{134}$ Into this rich field of Muslim apocalyptic, Juynboll observed that n-w-h-wailing terminology was used in reference to the impending fitna and Judgment Day:

Woe to the Arabs for evil is near ... Woe to the Arabs after Year 125 ... when the wailing weeping women will rise [taqūm al-näihāàt al-bākiyāt].

Juynboll reasoned that the hadith indicated a "vaticinatio post eventum" to date the emergence of niyăha wailing amongst Iraqi Muslims;, ${ }^{135}$ but we have seen that niya ha wa wa pre-Islamic practice of at least some Arabians, and the reference to $n \bar{a} i h \bar{a} t /$ wailers in apocalyptic contexts connected to the fall of cities and eschatological predictions of war and doom is moreover wider spread than the one example Juynboll identified from the juridical hadith collections.

133 Critiquing a trend in earlier scholarship that believed Muslims did not develop as sophisticated apocalyptic eschatology as Christianity and Judaism, David Cook's Studies in Muslim Apocalyptic (Princeton NJ: Darwin, 2002) reveals the breadth of material from Islam's first centuries. Apocalyptic material is particularly rich in early hadith collections, in particular Ibn Abī Shayba, Mușannaf, 21:23-355; Nu'aym ibn Ḥammād al-Marwazīs Kitāb al-Fitan, ed. Suhayl Zakkar (Beirut: Dār al-Fikr, 1993) is a rare surviving monograph devoted to diverse apocalyptic traditions from Islam's first two centuries. The retreat from 'apocalyptic' conceptions of history coincides with a similar shift from astrological historiography during the third/ninth century, as discussed in Antoine Borrut, "Court Astrologers and Historical Writing in Early Abbasid Baghdad," in The Place to Go: Contexts of Learning in Baghdad, 750-100o, eds. Jens Scheiner and Damien Janos (Princeton NJ: Darwin, 2014), 486-487.

134 The impact of the intra-communal warring on Muslim eschatological imaginations is manifest in the connections drawn between political events of the first centuries of Islam, caliphal succession, regional power blocs and predictions of the End of Days across the apocalyptic hadith, see al-Marwazì, al-Fitan, 52-315.

135 Juynbol, Muslim Tradition, 108. 
Al-Marwazīs (d. 229/844) Kitāb al-Fitan, the largest extant text devoted to Muslim apocalyptic material, narrates five detailed and portentous apocalyptic warnings in which wailers appear. Two are expansions of the hadith Juynboll cites, warning of disaster that will befall in the year 125 (742-743), two others refer to the capture of Egypt by "People of the West" (ahl al-maghrib), ${ }^{136}$ and another predicts the entrance of the Sufyānì (an eschatological figure of several guises) into Egypt:

When the Sufyānī enters Egypt, he will remain there four months, killing

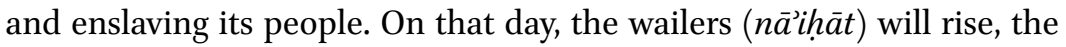
female mourners (bākiyāt) will bewail their rape, the killing of their children; they will mourn the passing of their might into humiliation; they will mourn, wishing they were already in their graves. ${ }^{137}$

The five apocalypses mentioning wailers are roughly contemporaneous. The first must have been written around the year 125/742-743 when the Umayyad house was teetering towards collapse and disorder was widespread. The genesis of the predicted invasions of the "People of the West" and the Sufyānī appear connected to the immediate aftermath of the Abbasid takeover in 132/750 when a large body of apocalyptic material emerged that purported to connect the Abbasid rise to a chain of events that proved the immanence of Judgment Day. ${ }^{138}$ Pro-Abbasid armies had taken the Caliphate from the East, hence the creators of our material presumed that the next takeover must originate in the West, followed by a resurrection of the Umayyads (the Sufyānī) which would be followed quickly by the Messiah and the End of Days.

In order to evaluate why niya ha a established itself as one of the tropes of apocalyptic discourses about the fall of cities and spread of disorder in the late Umayyad and early Abbasid periods, it would be useful to look deeper into the material from which Muslims derived this eschatology. Whilst political turmoil within the Muslim community offered the main inspiration for Muslim apocalyptic, Muslims borrowed ideas from the contemporaneously burgeoning Judeo-Christian apocalyptic too. Late Antique Judeo-Christian texts possessed a well-established trope of "wailing" that described the panic and worries of the damned upon impending Divine Judgment. The sentiment "wailing and gnashing of teeth" occurs eight times in the Gospels, particularly in Matthew, for example in the parable in Matt 24:50-51:

136 al-Marwazī, al-Fitan, 116, 117, 158, 159.

137 al-Marwazī, 173 .

138 See al-Marwazī, al-Fitan, ${ }_{115}^{-197 .}$ 
the master of that slave will come on a day when he does not expect [him] and at an hour which he does not know, and will cut him in pieces and assign him a place with the hypocrites; in that place there will be weeping [ $x \lambda \alpha v \theta \mu \dot{s} \varsigma]$ and gnashing of teeth. ${ }^{139}$

The Greek tradition uses the word $x \lambda \alpha v \theta \mu$ òs, connoting wailing and lamentation, and a related verb $x \lambda \alpha i \omega$ (weeping aloud, expressing uncontainable, audible grief) appears in Revelation 18:9 in the Lament over Babylon. Moreover, Revelation 1:7 adduces wailing upfront in its first reference to the Coming of Christ:

Behold, He is coming with the clouds, and every eye will see Him-even those who pierced Him. And all the tribes of the earth will mourn [ $x \circ \dot{\pi} \tau \omega]$ because of Him. So shall it be! Amen.

Kó $\pi \tau \omega$ is particularly expressive: it means to cut or smite, and, in the context intended by Revelation 1:7, to beat one's breast or head in lamentation. ${ }^{140}$ The same verb appears in Matthew 24:30's allusions to the coming of Christ, and the sentiment is repeated in the Hebrew Bible too, for example in the context of Zechariah 12:9-10's account of Jerusalem's final deliverance:

And in that day I will set about to destroy all the nations that come against Jerusalem. I will pour out on the house of David and on the inhabitants of Jerusalem, the Spirit of grace and of supplication, so that they will look on Me whom they have pierced; and they will mourn [saphad $]^{141}$ for Him, as one mourns for an only son, and they will weep bitterly over Him like the bitter weeping over a firstborn.

Hence the public act of wailing lament had cast a footprint in Judeo-Christian apocalyptic feeling about the End of Days, ${ }^{142}$ and with the opportunity Muslims possessed to employ these Judeo-Christian stories to articulate Muslim apocalyptic, Muslims faced the challenge of translating the material into Arabic. Juynboll's observation from the hadith and the additional eschatological texts from al-Marwazìs Kitāb al-Fitan reveal that niyāḥa stood-in as an Arabic lex-

139 New American Standard Bible translation. See also Mat 2:18, 8:12, 13:42, 13:50, 22:13, 25:30; Luke 13:28.

140 See Strong's Concordance 2875: Koptó.

141 The Hebrew saphad connotes wailing and lamentation.

142 See also Luke 8:52 and 23:27. 
ical choice to communicate the meaning of loud lamentation expressed in the Biblical uncontrolled wailing $x \lambda \alpha v \theta \mu \dot{s} \varsigma / x o ́ \pi \tau \omega$.

The intersection of niyăha with eschatology brings us to a crucial aspect of the Jähiliyya conceptual universe which also has been overlooked in modern scholarship. Contrary our current assumptions that Muslims equated alJähiliyya with pre-Islamic Arabia, the richest source of early Arabic references to al-Jāhiliyya was in fact forward looking: al-Jähiliyya was most frequently marshalled in hadith to describe the apocalyptic future and its violence and terror preceding the appearance of the future Messiah. The singular importance of this 'future Jähiliyya' in Muslim thought is quantifiable in Ibn Abī Shayba's al-Mușannaf: as noted above, al-Mușannaf invokes al-Jāhilizyya with extreme infrequency, but the one exception is the book's chapter on apocalyptic hadith, the Kitäb al-Fitan, which contains nine references to al-Jähiliyya to articulate the disorganised state of violence, profligacy and horror of the impending Apocalypse. Al-Jāhiliyya's $2.6 \%$ frequency in Kitāb al-Fitan's section on the warnings about future communal peril, ${ }^{143}$ compared to the $0.1 \%$ in the rest of al-Musannaf is striking: numerically, the association of al-Jāhiliyya with the future is twenty-five times more common in the fitna texts than its association with an Arabian past. The forward-looking Kitāb al-Fitan possesses a uniquely concentrated array of jāhiliyya compared to the rest of Ibn Abī Shayba's compendium.

To probe the chronologically-intriguing future al-Jāhiliyya, one hadith is particularly revealing: it states that the Arabs came from a Jähiliyya, that they were rescued by Muhammad, and that they will enter another Jähiliyya before the elect are saved by the Messiah. ${ }^{144}$ This hadith dovetails precisely with the first extant definition of al-Jāhiliyya in al-Khalī ibn Ahmad's (d. 175/791) Kitāb al-Ayn, the earliest surviving Arabic dictionary written when apocalyptic eschatology was in vogue in Muslim intellectual circles. ${ }^{145} \mathrm{Al}$-Ayn defines

143 The section on fitna contains 346 hadith (Ibn Abī Shayba, al-Mușannaf, 21:23-186), of which there are 9 references to Jähiliyya: hadith $38283,38305,38306,38313,38355,38398$, $38565,38605,38889$. There is also repeated reference to jahl descending on the community $(38279,38435,38729,38743)$ and people described as juhhäl (38745).

144 Ibn Abī Shayba, al-Muṣannaf, 21:37, hadith 38283. The prediction of an Arab passage from a pre- Muhammad al-Jāhiliyya, through Muhammad's prophecy and then thence into a new post- Muhammad al-Jāhiliyya is repeated in al-Marwazìs Kitāb al-Fitan, 238-239.

145 Borrut, "Court Astrologers," 487 notes the importance of astrological history and the interest in eschatological models of historiography up to the third/ninth century. The extant form of al-Khalīl ibn Ahmad's dictionary was altered by his student, al-Layth ibn al-Muzaffar (d. 200-815-816), but this is still within the period of historiography Borrut analyses. 
jāhiliyya as a period of al-fatra-al-fatra being defined as a period of time between two prophets. ${ }^{146} \mathrm{Al}$-'Ayn's definition thus decouples al-jăhiliyya from the time-space of pre-Islamic Arabia, and plots instead an open-ended theological notion of al-jāhiliyya as the situation of prophecy's absence. Such Jāhiliy$y a$-as-fatra model has ramifications from the perspective of Muslim historiography, for it outlines a cyclical model of history rather than linear. Linear history would posit al-Jāhiliyy $a$ as a past state eradicated by Muhammad, whereas a cyclical history of prophets alternating with fatras means that there was not one al-Jāhiliyya of pre-Islamic Arabia, and instead that there were multiple Jähiliyyas of dark and violent times ${ }^{147}$ in each of the gaps between the many prophets of the past.

When eschatological hadith in al-Musannaf refer to the future Jähiliyya, they intend that Muslims following the death of Muhammad will face one final period of confusion before the Messiah shall rescue the 'proper Muslims'. Here eschatology and politics blend: the identities of the saved elect of 'proper Muslims' are linked to the various camps competing over the theological/political leadership of the Caliphal system (al-Imäma), and the inter-Muslim warring across the Umayyad Caliphate was thereby interpreted as the onset of the final Jāhiliyya. The multiple references to fighting (haraj) and female decadence (tabarruj) in these future Jähilizyya hadith are the parameters of violence and moral decay imagined to be immanent, and Juynboll's hadith mentioning niya $h$ $a$ adds Biblical wailing into Muslim apocalyptic discourse to further populate their impressions of the terrible future with more tropes of anguish. In this vein, the reference to niya hạa is not specifically referencing the niya hạa ritual of pre-Islamic Arabian women mourning high-status men: there is no indication that funerary niya $\bar{a} a$ will get out of hand and bring society down, rather, the reference to niya ha hearkens the onset of the momentous event of the End of Days, making it an Arabic approximation for the Biblical terminology of how people will all lament and wail as Judgment draws near. Once wailing was associated with the world of al-jāhiliyya, however there was natural crossover, enabling jurists to add the terror of apocalyptic niyăha to their critiques of the actual practice of everyday niya $h \mathfrak{h a}$ at funerals. Hence the semantic universe of the word niyāhă had two separate geneses-funerary and apocalyptic

146 al-Khalīl ibn Aḥmad, al-'Ayn, eds. Mahdī al-Makhzūmī and Ibrāhīm al-Sammarā’ì (Baghdad: Wizārat al-Thaqāfa wa-l-I'lām, 1980), 3:39o ( jāhiliyya) and 8:115 ( fatra).

147 Al-jăhiliyya and the apocalyptic future are commonly adjective by words such as ' $a m y \bar{a}$ ' (blind) șammä' (deaf), z̧alima (dark) or jahlä' (ignorant/passionate)—see al-Marwazī, alFitan, 36, 98, 105, 111, 137 and al-Khalil ibn Aḥmad, al-Ayn, 3:39o. 
lamentation - but in the minds of jurists, both of these were self-evidently bad, and hence wailing and al-Jāhiliyya converged.

What is particularly intriguing for the story of niy $\bar{a} h a$ 's association with al-Jāhiliyya is a change in Arabic historiographical discourses around Anno 250. It has been proposed that the apocalyptic eschatology of early generations of Muslims lost popular favour after the Abbasid Caliphs returned from Samarra, ${ }^{148}$ and the ideas of future al-Jăhiliyya do diminish in the literature, as al-Jähiliyya became increasingly associated with the single historical period of past, pagan Arabia before Muhammad. ${ }^{149}$ Third/ninth century writing essentially forgot the future Jähiliyya in favour of associating the word as the signifier for pre-Muhammadic Arabia. In the process of the discursive shift, the semiotic signifieds of terrifying futurity conjured by the sign 'al-Jähiliyya' were thereby transported backwards in time in Muslim imaginations to be settled exclusively in pre-Islamic Arabia. This enabled Muslims of the fourth/tenth century and later to imagine the Arabs before Muhammad in ways that their forebears had apprehensively looked into the terrifying future, and hence killing, profligacy and niyäha came to stand as stereotypes of how Muslims came to imagine pre-Islamic Arabs. The shift may be best epitomised as a function of a conceptual switch from an "eschatological Jāhiliyya" to a "cultural Jāhiliyya" - the former constructed images of future apocalyptic confusion, the latter constituted a historic idea about pre-Islamic Arab identity. In the case of niya ha $a$, the fusing of apocalyptic sentiments onto a cultural construction of pan-Arabian Bedouin lamentation practice converged into a novel way of chiding pre-Islamic Arabs, and spawned the perceived prevalence of pre-Islamic Arabian niya h̆ha in Muslim imaginations to a level that far outstripped the prevalence of niyăha in pre-Islamic poetry itself.

Lastly, Juynboll and Halevi's observations that the most cutting prohibitions of niyāha and its association with al-Jāhiliyya issued from al-Kūfa can be further contextualised with reference to specifically Kufan communal concerns of the second/eighth century. Al-Küfa was a formative ground in which proto-Shi'a groups developed their beliefs, and one important aspect of Shi'a practice involved the commemoration of the death of their Imams. Early Shi'a

\footnotetext{
148 See above, note 145 .

149 The anticipation of an apocalyptic future inaugurated by fitna (communal, theologically infused fighting) declined in the third/ninth century, as the string of four fitnas ends with al-Ma'mūn's victory in the Fourth Fitna (193-211/8o9-820). Historians did not plot the subsequent strife in the Muslim community onto the fitna chronology, and the dictionary definitions and other glosses of al-Jāhiliyya also change-from the fourth/tenth century, emphasis shifts away from cyclical fatra periods between prophets to pre-Islamic Arabia, specifically (see Webb, "al-Jāhiliyya," 76-84).
} 
were drawn to ritual mourning and they discussed the proper rites that could be observed, gravitating towards public memorials of lamentation and standing about the Imam's shrines. ${ }^{150}$ As such, Shi'a Imam-veneration shared various rituals with funerary niyāha, and perhaps even borrowed from niyāha to reflect the high-status reverence that the proto-Shi'a communities had for their Imams. As divides between Shi'a and Sunna adherents became more pronounced in the second/eighth century and beyond, the așhäb al-hadith jurists grew increasingly aware of the needs to (a) distinguish themselves from the Shica and (b) censure Shica practices in order to bolster their own ostensible orthodoxy. The opportunity to equate Shi'a commemoration with the apocalyptic, un-Islamic practice and with al-Jāhiliyya is self-evidently valuable for Kufan hadith scholars, and their claims for niyāha's prohibition can be fruitfully read as backhanded slurs against early Shica, too.

The proposal that the express prohibitions of niya hạa were aggravated on account of proto-Sunni anti-Sh'ia agendas moreover corresponds with the two phenomena noted by Juynboll that anti-niya hạa hadith are (a) less frequent before the second/eighth century; and (b) initially absent in other centres of Islamic law, notably Egypt. This parallels the development of Shicism, since Imam-mourning was also a second/eighth century Iraqi phenomenon, apparently beginning near al-Küfa with ritual public mourning of al-Husayn at Karbala in 65/684, becoming a more central ritual over the course of the second/ eighth century, and thereby presenting contemporary Kufan proto-Sunni jurists with uniquely pressing reasons to reject niyāha, and to associate it with al-Jāhiliyya in order to bolster their own agendas.

Alongside the spread of Shi ism, the development of Muslim communities after Anno 250 also brought new demographic changes. The formerly rigorous distinction between Arabian Conqueror and local conquered blurred in the cosmopolitan centres of the Caliphate, and the status of the Arabian Conqueror groups gradually decreased to virtual insignificance by the end of the third/ninth century. ${ }^{151}$ In such an environment, when most of the now extant literature was written, niya ha ha was inevitably associated with a sense of pastness: the earlier trappings of Arabian customs were disappearing in contemporary society as the military and the ranks of court nobility dissociated from earlier tribal blocs and discarded some of the trappings of the old Arab elite

150 See the discussion in Najam Haider, "Prayer, Mosque and Pilgrimage: Mapping the Shi'a Sectarian Identity in 2nd/8th Century Küfa," Islamic Law and Society 16 (2009): 151-174.

151 The rise of new elites is much discussed, the most detailed study is Matthew Gordon, The Breaking of a Thousand Swords (Albany NY: SUNY, 2001), see particularly $75-88,111-118$. The specific ramifications for Arabness are considered in Webb, Imagining the Arabs, 274-278. 
identity. ${ }^{152}$ In this context, values of the earlier Muslim military elite, like their penchant for niyāha, may have seemed antiquated, especially given (i) the contemporaneous rise of anti-Shi'a discourses, (ii) niyähạ's theoretical dissonance with Islamic views on death, and (iii) niyāha a's association with al-jāhiliyya. In the generations following Anno 250, the seminal shifts in thinking from an eschatological-apocalyptic Jāhiliyya to a historic-cultural Arabian al-Jāhiliyya could further and firmly associate niyăha with perceptions of a past, antiquated and repudiated Jahhiliyya of pre-Islamic Arabness. And consequently, a broad array of social and intellectual forces swelled a negative opinion of lamentation practice and encased it within a repudiated air of past Arabian folly.

In conclusion, Juynboll's impression of niya h̆ha needs an amendment: the form of lamentation was not adopted by Muslims during the Islamic period de novo, rather the conceptual path of ideas connected to niyanha during the course of Islam's first three centuries navigated an array of novel issues and associations which clustered around niyăha and eventually prompted a backtracking of the practice that inserted it into memories of pre-Islamic Arabica. Pre-Islamic poetry itself is not particularly rich in describing niyāha, but we have offered explanations for the ways in which Muslims gradually reconceptualised pre-Islam, inflating the perceived salience of niyăha $a$ as a quintessential 'Jähiliyya trait' in the process. Given the presence of niyāha in preIslamic poetry, we can discern that Muslim writers did not strictly invent the past, but their particular motivations and interests wrapped their present concerns into different guises that helped them shape impressions about Arabia before Muhammad. Memories about the institution of niyăha wailing were accordingly embellished for reasons quite separate from the realities of preIslamic Arabia, and we cannot therefore take the word of third/ninth and fourth/tenth century Arabic writings about al-Jāhiliyya at face value, but likewise, the reasons for the promotion of niyāha as emblematic of al-Jāhiliyya had very particular drivers which may not have been operative in Muslim reconstructions of different aspects of pre-Islam.

$15^{2}$ The surprisingly stark disappearance of Arab tribal affiliations in urban Iraqi society is noted in the quantitative studies of biographical dictionaries compiled by Judith Ahola ("The Community of Scholars: An Analysis of the Biographical Data from the Tarīkh Baghdād" [unpublished PhD diss., University of St. Andrews, 2004]) and Maxim Romanov ("Computational Reading of Arabic Biographical Collections with Special Reference to Preaching in the Sunnī World (661-130o CE)" [unpublished PhD diss., University of Michigan, 2013]), see discussion of both theses in Webb, Imagining the Arabs, 273-277. 
The differing significations and functions between the eschatological-apocalyptic and cultural-historical jāhiliyyas appear worthy of further evaluation, and this paper's arguments accordingly cannot explain all aspects of al-Jāhiliy$y a$ in the Muslim imaginary. We operated upon the massive edifice with the smallest of tools to explore the contours of just one ritual and its memorialisation, yet in so doing, we uncovered intriguing results, and the path ahead will hopefully benefit from more studies targeted at other specific icons of al-Jähiliyya, eventually laying bare for us the manifold pathways by which Muslims have constructed their imagined pre-Islamic Arab.

\section{Bibliography}

Abū Dāwūd. Sunan Abī Dāwūd. Riyadh: Dār al-Salām, 1999.

Ahola, Judith. "The Community of Scholars: An Analysis of the Biographical Data from the Ta'rikkh Baghdād." Unpublished PhD diss., University of St. Andrews, 2004.

'Alī, Jawād. Al-Mufașsal fì tārükh al-'arab qabla al-Islām. Beirut: Dār al-'Ilm li-l-Malāȳ̄n, 1968-1973.

al-Așmā̄ī, 'Abd al-Malik ibn Qurayb. Al-Așma ìyyāt. Edited by Muhammad Nabīl Ṭarīfi. Beirut: Dār Șādir, 2005.

Athamina, Khalil. "A'rāb and Muhājirūn in the Environment of Amșār." Studia Islamica 66 (1987): $5^{-25}$.

al-Azharī, Muḥammad ibn Aḥmad. Tahdhīb al-lugha, vol. 4. Edited by Muḥammad 'Abd al-Raḥmān Mukhaymir. Beirut: Dār al-Kutub al-'Ilmiyya, 2004.

al-Azmeh, Aziz. The Arabs in Islam. Berlin: Gerlach, 2014.

al-Azmeh, Aziz. The Emergence of Islam in Late Antiquity. Cambridge: Cambridge University Press, 2014.

al-Bașrī, Alī ibn Abī al-Faraj. Al-Hamāsa al-Bașriyya. Edited by 'Adil Sulaymān Jamāl. Cairo: al-Khānjī, 1999.

Borrut, Antoine. "Court Astrologers and Historical Writing in Early Abbasid Baghdad." In The Place to Go: Contexts of Learning in Baghdad, 750-1000, edited by Jens Scheiner and Damien Janos, 455-501. Princeton NJ: Darwin, 2014.

al-Bukhārī. Șahīh al-Bukhārī. Riyadh: Dār al-Salām, 1999.

Conrad, Lawrence. "The Arabs." In The Cambridge Ancient History, vol. 14, Late Antiquity: Empire and Successors, AD 425-60o, edited by Averil Cameron, Bryan WardPerkins and Michael Whitby, 678-70o. Cambridge: Cambridge University Press, 2001.

Cook, David. Studies in Muslim Apocalyptic. Princeton NJ: Darwin, 2002.

Cooperson, Michael. Classical Arabic Biography. Cambridge: Cambridge University Press, 2000. 
Crone, Patricia. "The First-Century Concept of Higra." Arabica 41 (1994): 352-387.

Drory, Rina. "The Abbasid Construction of the Jāhiliyya: Cultural Authority in the Making." Studia Islamica 83 (1996): 33-49.

El Cheikh, Nadia. Women, Islam and Abbasid Identity. Cambridge MA: Harvard, 2015.

El Tayib, Abdulla. "Pre-Islamic Poetry." In Arabic Literature to the End of the Umayyad Period, edited by A.F.L. Beeston et al. Cambridge: Cambridge University Press, 1983.

Fahd, Toufic. "Niyāha." In Encyclopaedia of Islam, 2nd edition, vol. 8. Edited by C.E. Bosworth, E. van Donzel, W.P. Heinrichs and G. Lecomte, 64-65. Leiden: Brill, 1995.

Fiema, Zbigniew T., Ahmad Al-Jallad, Michael C.A. Macdonald and Laïla Nehmé. "Provincia Arabia: Nabataea, the Emergence of Arabic as a Written Language, and Graeco-Arabica." In Arabs and Empires before Islam, edited by Greg Fisher, 373-433. Oxford: Oxford University Press, 2015.

Fisher, Greg. "Editor's Introduction." In Arabs and Empires before Islam, edited by Greg Fisher, 1-10. Oxford: Oxford University Press, 2015.

Fisher, Greg. "Kingdoms or Dynasties: Arabs, History and Identity before Islam." Journal of Late Antiquity 4 (2011): 248-249.

Goldziher, Ignaz. Muslim Studies. Edited by S.M. Stern, translated by C.R. Barber and S.M. Stern. London: George Allen \& Unwin, 1967-1971.

Gordon, Matthew. The Breaking of a Thousand Swords. Albany Nw: SUNY, 2001.

Haider, Najam. "Prayer, Mosque and Pilgrimage: Mapping the Shi'a Sectarian Identity in 2nd/8th Century Kūfa." Islamic Law and Society 16 (2009): 151-174.

Halevi, Leor. "Wailing for the Dead: The Role of Women in Early Islamic Funerals." Past \& Present 183 (2004): 3-39.

Hawting, Gerald. The Idea of Idolatry and the Emergence of Islam. Cambridge: Cambridge University Press, 1999.

al-Ḥimyarī, Nashwān. Shams al-'ulūm. Edited by Ḥusayn ibn 'Abd Allāh al-'Umarī. Damascus: Dār al-Fikr, 1999.

Homerin, Thomas Emil. "Echoes of a Thirsty Owl: Death and Afterlife in Pre-Islamic Arabic Poetry." Journal of Near Eastern Studies 44 (1985):165-184.

Hoyland, Robert. Arabia and the Arabs. London: Routledge, 2001.

Ibn 'Abd Rabbihi. al-'Tqd al-farīd. Edited by Ibrāhīm al-Abyārī. Beirut: Dār al-Kitāb al'Arabī, n.d.

Ibn Abī Shayba. Al-Muṣannaf. Edited by Muḥammad 'Awwāma. Jeddah: Dār al-Qibla, 2006.

Ibn Aḥmad, al-Khalīl. Al-'Ayn. Edited by Mahdī al-Makhzūmī and Ibrāhīm al-Sāmarrāīè. Baghdad: Wizārat al-Thaqāfa wa-l-I'lām, 198 o.

Ibn Durayd, Abū Bakr Muḥammad. Jamharat al-lugha. Edited by Ramzī Bacalbakī. Beirut: Dār al-'Ilm li-l-milāyīn, 1987.

Ibn Fāris, Aḥmad. Maqāyīs al-lugha. Edited by ‘Abd al-Salām Muḥammad Hārūn. Damascus: Ittihāe al-Kuttāb al-'Arab, 2002. 
Ibn Ḥabīb, Muḥammad. Al-Muhabbar. Edited by Ilse Lichtenstadter. Hyderabad, 1942. Ibn Mājah. Sunan Ibn Mājah. Riyadh: Dār al-Salām, 1999.

Ibn Manẓūr. Lisān al-'Arab. Beirut: Dār Șādir, 1990.

Ibn Qutayba. Fạ̣l al-'Arabwa-l-tanbīh 'alā 'ulūmihāa Edited by Walīd Khāliṣ. Abu Dhabi: al-Majma` al-Thaqāfì, 1998.

Izutsu, Toshihiko. Ethico-Religious Concepts in the Qur'ān. Montreal: McGill, 2002.

Jones, Alan. "The Oral and the Written: Some Thoughts about the Quranic Text." In Proceedings of the Colloquium on Logos, Ethnos, Mythos in the Middle East and North Africa Part One: Linguistics and Literature, edited by Kinga Dévényi and Tamás Iványi, 57-66. Budapest: Eötvös Loránd University \& Csoma de Körös Society Section of Islamic Studies, 1996.

Juynboll, Gautier H.A. Muslim Tradition: Studies in Chronology, Provenance and Authorship of Early Hadith Cambridge: Cambridge University Press, 1983.

Kister, Meir J. “'Do Not Assimilate Yourselves ...': Lā Tashabbahū.” Jerusalem Studies in Arabic and Islam 12 (1989): 321-371.

Labīd. Dīwān. Edited by Iḥsān 'Abbās. Kuwait: Wizārat al-Irshād wa-l-Anbā', 1962.

Lindstedt, Ilkka. "Muhājirūn as a Name for the First/Seventh Century Muslims." Journal of Near Eastern Studies 74 (2015): 67-73.

Lucas, Scott. "Where are the Legal Hadith? A Study of the Muṣannaf of Ibn Abī Shayba." Islamic Law and Society 15 (2008): 283-314.

al-Marzūqī. Sharh Dēwān al-Hamāsa. Edited by Aḥmad Amīn and 'Abd al-Salām Hārūn. Cairo: Mațba'at Lajnat al-Ta'liff wa-l-Tarjama wa-l-Nashr, 1968.

al-Marwaz̄̄, Nu'aym ibn Ḥammād. Kitāb al-Fitan. Edited by Suhayl Zakkā. Beirut: Dār al-Fikr, 1993.

Montgomery, James E. “The Empty Hijāz." In Arabic Theology, Arabic Philosophy: From the Many to the One: Essays in Celebration of Richard M. Frank, edited by James E. Montgomery, 37-97. Leuven: Peeters, 2006.

Motzki, Harold. "The Muṣannaf of 'Abd al-Razzāq Al-San'ānī as a Source of Authentic A Ḥādīth of the First Century A.H." Journal of Near Eastern Studies 50 (1991): 1-21.

al-Mubarrad, Abū al-'Abbās Muhammad. Kitāb al-Ta'āzī wa-l-marāthī. Edited by Khalīl Manșūr. Beirut: Dār al-Kutub al-'Ilmiyya, 1996.

al-Mubarrad, Abū al-'Abbās Muḥammad. Al-Kāmil. Edited by Muḥammad Aḥmad alDālī. Beirut: Mu’assasat al-Risāla, 2008.

Muslim. Șaḥịh Muslim. Riyadh: Dār al-Salām, 1999.

al-Nābigha al-Dhubyānī. Dōwān. Edited by Muhammad Abū al-Faḍl Ibrāhīm. Cairo: Dār al-Ma'̄ārif, 1990.

al-Nasā'̄ì, Aḥmad Ibn Shu'ayb. Sunan al-Nasā’̀̄. Riyadh: Dār al-Salām, 1999.

al-Nuwayrī, Shihāb al-Dīn. Nihāyat al-arab fí funūn al-adab. Edited by Ḥasan Nūr alDīn. Beirut: Dār al-Kutub al-'Ilmiyya, 2004.

Peters, Francis E. The Hajj. Princeton: Princeton University Press, 1994. 
Romanov, Maxim. "Computational Reading of Arabic Biographical Collections with Special Reference to Preaching in the Sunnī World (661-13oo CE)." Unpublished PhD diss., University of Michigan, 2013.

Shahid, Irfan. Byzantium and the Arabs. Washington DC: Dumbarton Oaks, 1984-20o9.

Shahid, Irfan. "The 'Sūra' of the Poets Revisited." Journal of Arabic Literature 39 (2008): $398-423$.

Steppat, Fritz. “Those who believe and have not emigrated': The Bedouin as the Marginal Group of Islamic Society." In Islão e Arabismo na Península Ibérica: Actas do XI Congresso da União Europeia de Arabistas e Islamólogos, edited by Adel Sidarus, 403-412. Évora: Universidade de Évora, 1986.

Stetkevych, Susan. "The 'Abbasid Poet Interprets History: Three Qașīdahs by Abū Tammām." Journal of Arabic Literature 10 (1979): 49-64.

al-Sukkarī, Abū Sa'īd al-Ḥasan. Sharh ash'ār al-Hudhaliyyīn. Edited by 'Abd al-Sattār Aḥmad Farrāj and Maḥmūd Muḥammad Shākir. Cairo: Maktabat Dār al-'Urūba, n.d. Ṭarafa ibn 'Abd, Dīwān. Edited by Duriyya al-Khațīb and Luṭ̂ī al-Ṣaqqāl. Beirut: alMu'assasat al-'Arabiyya li-l-Dirāsa wa-l-Nashr, 2000.

al-Ṭā'ī, Abū Zubayd. Dīwān. Edited by Nūrī Hamūdī al-Qaysī. Baghdad: al-Ma‘ārif, 1967 . al-Tirmidhī. Jāmic. Riyadh: Dār al-Salām, 1999.

Webb, Peter. “Al-Jāhiliyya: Uncertain Times of Uncertain Meanings.” Der Islam 91, no. 1 (2014): 69-94.

Webb, Peter. “Review of Aziz al-Azmeh's The Emergence of Islam in Late Antiquity." 'Ușūr al-Wusțā 23 (2015): 149-153.

Webb, Peter. "Review of Greg Fisher's Arabs and Empires in before Islam." Bulletin of the School of Oriental and African Studies 79, no. 3 (2016): 640-642.

Webb, Peter. Imagining the Arabs. Edinburgh: Edinburgh University Press, 2016.

Zwettler, Michael. "The Sura of the Poets: Final Conclusions?" Journal of Arabic Literature 38 (2007): 111-161. 